\title{
A tropospheric ozone maximum over the equatorial Southern Indian Ocean
}

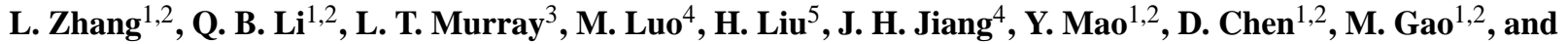 \\ N. Livesey ${ }^{4}$ \\ ${ }^{1}$ Department of Atmospheric and Oceanic Sciences, University of California, Los Angeles, CA, USA \\ ${ }^{2}$ Joint Institute for Regional Earth System Science and Engineering, University of California, Los Angeles, CA, USA \\ ${ }^{3}$ School of Engineering and Applied Sciences, Harvard University, Cambridge, MA, USA \\ ${ }^{4}$ Jet Propulsion Laboratory, California Institute of Technology, CA, USA \\ ${ }^{5}$ National Institute of Aerospace, Hampton, VA, USA
}

Correspondence to: Q. B. Li (qli@atmos.ucla.edu)

Received: 13 December 2011 - Published in Atmos. Chem. Phys. Discuss.: 20 January 2012

Revised: 27 April 2012 - Accepted: 2 May 2012 - Published: 14 May 2012

\begin{abstract}
We examine the distribution of tropical tropospheric ozone $\left(\mathrm{O}_{3}\right)$ from the Microwave Limb Sounder (MLS) and the Tropospheric Emission Spectrometer (TES) by using a global three-dimensional model of tropospheric chemistry (GEOS-Chem). MLS and TES observations of tropospheric $\mathrm{O}_{3}$ during 2005 to 2009 reveal a distinct, persistent $\mathrm{O}_{3}$ maximum, both in mixing ratio and tropospheric column, in May over the Equatorial Southern Indian Ocean (ESIO). The maximum is most pronounced in 2006 and 2008 and less evident in the other three years. This feature is also consistent with the total column $\mathrm{O}_{3}$ observations from the Ozone Mapping Instrument (OMI) and the Atmospheric Infrared Sounder (AIRS). Model results reproduce the observed May $\mathrm{O}_{3}$ maximum and the associated interannual variability. The origin of the maximum reflects a complex interplay of chemical and dynamic factors. The $\mathrm{O}_{3}$ maximum is dominated by the $\mathrm{O}_{3}$ production driven by lightning nitrogen oxides $\left(\mathrm{NO}_{\mathrm{x}}\right)$ emissions, which accounts for $62 \%$ of the tropospheric column $\mathrm{O}_{3}$ in May 2006. We find the contribution from biomass burning, soil, anthropogenic and biogenic sources to the $\mathrm{O}_{3}$ maximum are rather small. The $\mathrm{O}_{3}$ productions in the lightning outflow from Central Africa and South America both peak in May and are directly responsible for the $\mathrm{O}_{3}$ maximum over the western ESIO. The lightning outflow from Equatorial Asia dominates over the eastern ESIO. The interannual variability of the $\mathrm{O}_{3}$ maximum is driven largely by the anomalous anti-cyclones over the southern Indian Ocean in May 2006 and 2008. The lightning outflow from Central
\end{abstract}

Africa and South America is effectively entrained by the anticyclones followed by northward transport to the ESIO.

\section{Introduction}

Ozone $\left(\mathrm{O}_{3}\right)$ in the tropical upper troposphere is an effective greenhouse gas (Lacis et al., 1990). Ozone is also an important tropospheric oxidant and modulates the oxidizing power of the troposphere through photolysis in the presence of water vapor that generates hydroxyl radical $(\mathrm{OH})$, the main atmospheric oxidant (Levy, 1971; Logan et al., 1981). Production of tropical tropospheric $\mathrm{O}_{3}$ is driven by nitrogen oxides $\left(\mathrm{NO}_{\mathrm{x}}=\mathrm{NO}+\mathrm{NO}_{2}\right)$ emitted from primarily lightning (e.g., Sauvage et al., 2007; Ziemke et al., 2009) and biomass burning (e.g., Fishman et al., 1990; Jacob et al., 1996; Thompson et al., 2001; Logan et al., 2008). Large-scale dynamics is another prominent factor in controlling tropical tropospheric $\mathrm{O}_{3}$ distributions (e.g., Chandra et al., 2009; Zhang et al., 2011; Oman et al., 2011, and references therein).

The present study is motivated by an observed tropospheric $\mathrm{O}_{3}$ maximum in May over the southern tropical Indian Ocean from observations by the Microwave Limb Sounder (MLS), the Tropospheric Emission Spectrometer (TES), the Ozone Mapping Instrument (OMI) aboard the Aura satellite, and the Atmospheric Infrared Sounder (AIRS) aboard Aqua (detailed discussions in Sect. 4). Such an $\mathrm{O}_{3}$ maximum was indicated in previous observations (e.g., 


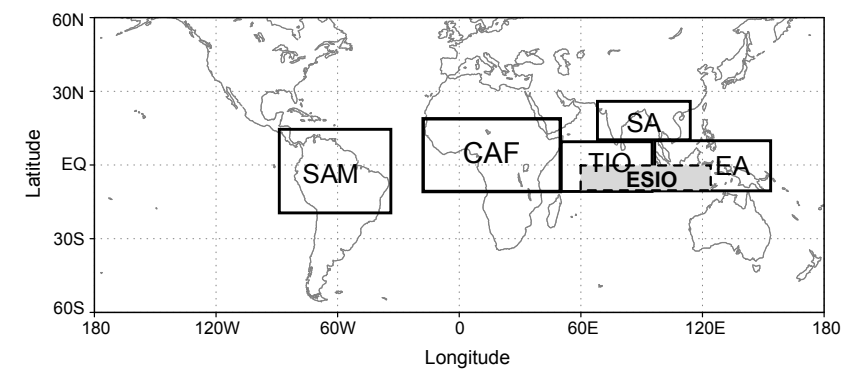

Fig. 1. The Equatorial Southern Indian Ocean (ESIO, $10^{\circ} \mathrm{S}-$ equator, $60^{\circ} \mathrm{E}-125^{\circ} \mathrm{E}$; shaded area) and five tropical lightning regions: the tropical Indian Ocean (TIO: $10^{\circ} \mathrm{S}-10^{\circ} \mathrm{N}, 40^{\circ} \mathrm{E}-$ $\left.95^{\circ} \mathrm{E}\right)$, South Asia $\left(\mathrm{SA}: 10^{\circ} \mathrm{N}-30^{\circ} \mathrm{N}, 70^{\circ} \mathrm{E}-110^{\circ} \mathrm{E}\right)$, Equatorial Asia (EA: $\left.10^{\circ} \mathrm{S}-10^{\circ} \mathrm{N}, 95^{\circ} \mathrm{E}-150^{\circ} \mathrm{E}\right)$, Central Africa $\left(\mathrm{CA}: 10^{\circ} \mathrm{S}-\right.$ $20^{\circ} \mathrm{N}, 20^{\circ} \mathrm{W}-40^{\circ} \mathrm{E}$ ) and South America (SAM: $20^{\circ} \mathrm{S}-15^{\circ} \mathrm{N}$, $\left.85^{\circ} \mathrm{W}-35^{\circ} \mathrm{W}\right)$.

Komala et al., 1996; Ziemke et al., 2009). We investigate here the origin of this $\mathrm{O}_{3}$ maximum and its interannual variability by interpreting the satellite observations using a global three-dimensional (3-D) chemical transport model (CTM). We intend to delineate the relative influence of biomass burning, lightning, and dynamics in controlling the $\mathrm{O}_{3}$ maximum. Much of our analysis focuses on the Equatorial Southern Indian Ocean $\left(10^{\circ} \mathrm{S}\right.$-equator (EQ) latitudes, $60^{\circ} \mathrm{E}-125^{\circ} \mathrm{E}$ longitudes), referred to hereafter as ESIO (the shaded rectangle in Fig. 1).

We give a brief description of the observations in Sect. 2 . Section 3 describes the GEOS-Chem model and simulations. Seasonal variations of tropospheric $\mathrm{O}_{3}$ in 2006 over the ESIO are discussed in Sect. 4. The lightning impact on tropospheric $\mathrm{O}_{3}$ over the region is examined in Sect. 5. Section 6 investigates the interannual variability of the tropospheric $\mathrm{O}_{3}$ enhancements over the ESIO. The results and discussion are summarized in Sect. 7.

\section{Observations}

\subsection{MLS O 3}

The Microwave Limb Sounder (MLS) (Waters et al., 2006) aboard the EOS Aura spacecraft (Schoeberl et al., 2006) has been measuring atmospheric parameters since August 2004. MLS uses microwave limb sounding to measure temperature and chemical constituents, including $\mathrm{CO}, \mathrm{O}_{3}$, water vapor, and cloud ice water content in the upper troposphere and lower stratosphere. MLS measurements in the upper troposphere are generally not degraded by the presence of clouds and aerosols because the typical cloud and aerosol particle sizes are generally much smaller than the measurement wavelengths. MLS measures $\sim 3500$ vertical profiles per day along a sun-synchronous polar orbit, with an equatorcrossing time of $\sim 13: 45$ local time. The data are produced

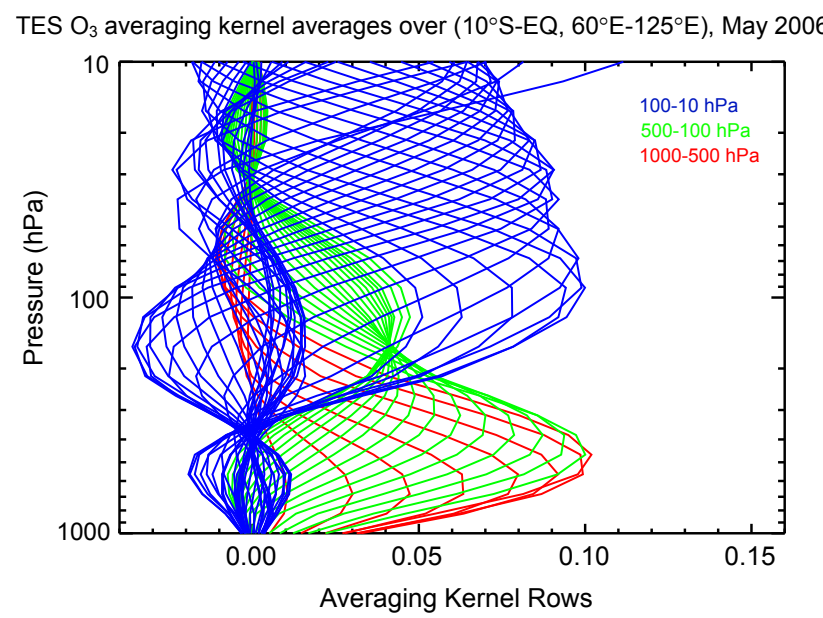

Fig. 2. TES $\mathrm{O}_{3}$ averaging kernel (between 1000 and $10 \mathrm{hPa}$ ), averaged for May 2006 over the Equatorial Southern Indian Ocean (see Fig. 1).

on pressure surfaces from 316 to $0.1 \mathrm{hPa}$. MLS data has a vertical resolution of $\sim 3-4 \mathrm{~km}$ and horizontal resolutions of $\sim 7 \mathrm{~km}$ across-track and $\sim 200-300 \mathrm{~km}$ along-track (Livesey et al., 2006). We use here $\mathrm{O}_{3}$ from MLS Version 3.3 (v3.3) Level 2 data (Livesey et al., 2011). Livesey et al. (2008) reported the validation of an earlier version of $\mathrm{MLS} \mathrm{O}_{3}$ (v2.2). The estimated accuracies of MLS v2.2 $\mathrm{O}_{3}$ are $\sim 20 \mathrm{ppbv}$ $(+20 \%)$ at $215 \mathrm{hPa}$ and $40 \mathrm{ppbv}(+5 \%)$ at $147 \mathrm{hPa}$. The systematic errors of MLS v3.3 $\mathrm{O}_{3}$ are consistent with those of v2.2 (Livesey et al., 2011). Our analysis focuses on the observations at 147 and $215 \mathrm{hPa}$ in the upper troposphere. For the present study, the Level 2 MLS data are averaged onto $2^{\circ}$ latitude $\times 5^{\circ}$ longitude grids for every five days as well as monthly from 2005 to 2009 . The precision of the $\mathrm{O}_{3}$ retrieval in the Level 2 data is $5-100 \%$ from 261 to $150 \mathrm{hPa}$ for single measurement (Livesey et al., 2011). The averaged precisions are up to $\sim 8 \%$ for the 5-day averages and $\sim 4 \%$ for the monthly averages over the ESIO.

\section{2 $\mathrm{TES} \mathrm{O}_{3}$}

The Tropospheric Emission Spectrometer (TES) is an infrared, high-resolution, Fourier Transform spectrometer covering the spectral range between 3.3 and $15.4 \mu \mathrm{m}$ (Beer et al., 2001; Beer, 2006). It was launched on board Aura (Schoeberl et al., 2006) in July 2004 in a sun-synchronous polar orbit. TES provides global vertically resolved measurements of tropospheric $\mathrm{O}_{3}, \mathrm{CO}$ and other atmospheric constituents. TES retrievals have been previously described by Bowman et al. (2006) and Kulawik et al. (2006). For the $\mathrm{O}_{3}$ retrieval, the prior information is derived from a global model simulation using the Model for OZone And Related chemical Tracers (MOZART, v2) (Horowitz et al., 2003; Brasseur et al., 1998). We use data from TES global surveys, with 16 orbits per global survey, over a time period of $26 \mathrm{~h}$ (Osterman et 
al., 2008). The nadir $\mathrm{O}_{3}$ vertical profiles are spaced $\sim 182 \mathrm{~km}$ apart along the orbit track and have a footprint of $5 \mathrm{~km}$ by $8 \mathrm{~km}$ (Beer et al., 2001). Under clear sky the vertical resolution of TES $\mathrm{O}_{3}$ profile retrievals is typically $6 \mathrm{~km}$ in the tropics (Jourdain et al., 2007). The TES averaging kernel shows the pressure levels where the retrieval is sensitive to and loosely indicates the vertical resolution of the retrieved profile (Bowman et al., 2006; Worden et al., 2007). Typical TES averaging kernels for $\mathrm{O}_{3}$ are shown in Worden et al. (2007), Osterman et al. (2008) and Shim et al. (2009). As an illustration, Fig. 2 shows a TES averaging kernel for profiles averaged in May 2006 over the ESIO. The averaged degree of freedom for signal (DOFs) is 1.5 in the troposphere between $1000-100 \mathrm{hPa}$, suggesting that there are more than one pieces of information in the retrieval and that the profile can be interpreted as distinguishing the upper troposphere versus the middle and lower troposphere.

TES Level 3 gridded data are the species profile interpolated (daily) or averaged (monthly) into uniform longitudelatitude grid from Level 2 data. The precision of a TES $\mathrm{O}_{3}$ profile is $5 \%-10 \%$ in the troposphere. The monthly averaged a few hundreds of $\mathrm{O}_{3}$ profiles would reduce the precision to less than $1 \%$ over the ESIO, much smaller than the variability in $\mathrm{O}_{3}$ field in the region. Here we use Version 3 (v3) Level $3 \mathrm{O}_{3}$ data (Osterman et al., 2008), including mixing ratio, $\mathrm{TCO}$, and total column $\mathrm{O}_{3}$ data from 2005 to 2009 , monthly averaged at $2^{\circ}$ (latitude) $\times 4^{\circ}$ (longitude) grids. The TES column values (e.g., TCO) were computed by integrating the retrieved profile up to the tropopause pressure as provided in the GEOS-4 meteorological fields (Bloom et al., 2005; Osterman et al., 2008) (see Sect. 3 for more details on the GEOS-4 data). Validation of TES tropospheric $\mathrm{O}_{3}$ retrievals against ozonesonde and lidar measurements shows a positive bias of $\sim 3-10$ ppbv (Nassar et al., 2008). The bias of TES TCOs is known to be high by $\sim 4 \mathrm{DU}$ in comparison with ozonesonde data (Osterman et al., 2008).

\subsection{OMI and AIRS total column $\mathrm{O}_{3}$}

The Ozone Monitoring Instrument (OMI) aboard Aura is a nadir-viewing, wide-swath hyper-spectral imaging spectrometer that provides daily global coverage with high spatial and spectral resolutions (Levelt et al., 2006b). It detects backscattered solar radiance in the ultraviolet-visible wavelengths $(0.27$ to $0.5 \mu \mathrm{m})$ to measure column $\mathrm{O}_{3}$ and other trace constituents and aerosols (Levelt et al., 2006a). OMI data has a spatial resolution of $13 \times 24 \mathrm{~km}^{2}$ at nadir.. Here we use the Level 3 Version 003 (V003) of daily OMI-TOMS (OMTO3) total column $\mathrm{O}_{3}$ binned onto a $1^{\circ}$ (latitude) $\times 1^{\circ}$ (longitude) grid from 2005 to 2009, which are derived from the TOMS (version 8) algorithm. The accuracy and precision of the OMTO3 total column $\mathrm{O}_{3}$ data is similar to the legacy Total Ozone Mapping Spectrometer (TOMS) data started in 1978, except over cloudy areas where OMTO3 data are more accurate than that of the TOMS (see http://toms.gsfc.
nasa.gov/omi/OMTO3_README_v8_5.pdf). Based on experience with TOMS, the total $\mathrm{O}_{3}$ data provided in OMTO3 should have a root-mean squared error of 1-2\%, depending on solar zenith angle, aerosol amount, and cloud cover. Validation of the OMI total column $\mathrm{O}_{3}$ against ground-based observations by Brewer/Dobson spectrophotometer instruments shows generally a better than $1 \%$ agreement (Balis et al., 2007; McPeters et al., 2008).

The Atmospheric Infrared Sounder (AIRS) (Aumann et al., 2003) is a high spectral resolution infrared sounder flown aboard the Aqua spacecraft (Parkinson, 2003) and has been operational since September 2002. Aqua is in a sun-synchronous polar orbit, with an equatorial crossing of 13:30 local time, covering the earth twice a day. Validation of AIRS total column $\mathrm{O}_{3}$ against ground-based Brewer/Dobson measurements shows a bias of less than $4 \%$ and a root-mean-square error of approximately $8 \%$ (Divakarla et al., 2008). We use AIRS Version 5 (V5) Level 3 monthly total column $\mathrm{O}_{3}$ binned onto a $1^{\circ}$ (latitude) $\times 1^{\circ}$ (longitude) grid from 2005 to 2009.

\section{GEOS-Chem model description and simulations}

GEOS-Chem is a global 3-D CTM driven by assimilated meteorological observations from the Goddard Earth Observing System (GEOS) of the NASA Global Modeling and Assimilation Office (GMAO) (Bey et al., 2001). We use GEOSChem version 8-01-04 (http://acmg.seas.harvard.edu/geos/) driven by GEOS-4 and GEOS-5 meteorological fields with 6-h temporal resolution (3-h for surface variables and mixing depths), $2^{\circ}$ (latitude) $\times 2.5^{\circ}$ (longitude) horizontal resolution, and 30 (GEOS-4) or 47 (GEOS-5) vertical layers between the surface and $0.01 \mathrm{hPa}$. The GEOS-Chem model includes a detailed description of tropospheric $\mathrm{O}_{3}-\mathrm{NO}_{\mathrm{x}}-$ hydrocarbon chemistry coupled with aerosol chemistry (Bey et al., 2001). Gas phase chemical reaction rates and photolysis cross sections are taken from Sander et al. (2000). Photolysis frequencies are computed using the Fast-J algorithm (Wild et al., 2000). The cross-tropopause $\mathrm{O}_{3}$ flux is specified with the "synthetic ozone" (Synoz) method (McLinden et al., 2000) as implemented by Bey et al. (2001). Synoz includes a passive, ozone-like tracer released into the stratosphere at a rate that results in a prescribed cross-tropopause $\mathrm{O}_{3}$ flux (McLinden et al., 2000), thereby ensuring that downward ozone flux from the stratosphere is not overestimated. The cross-tropopause $\mathrm{NO}_{y}$ flux is calculated from $\mathrm{N}_{2} \mathrm{O}$ oxidation in the model stratosphere (Bey et al., 2001). The global net cross-tropopause fluxes of $\mathrm{O}_{3}$ and $\mathrm{NO}_{\mathrm{y}}$ are $495 \mathrm{Tg} \mathrm{O}_{3} / \mathrm{yr}$ and $0.5 \mathrm{Tg} \mathrm{N} / \mathrm{yr}$, respectively in the model (Hudman et al., 2007). The GEOS-Chem model also includes a linearized ozone ("Linoz") parameterization scheme based on the work by McLinden et al. (2000) to represent the ozone in the stratosphere, in which the ozone vertical profiles across the tropopause are relaxed back toward climatological profiles. 
The Synoz scheme may not correctly capture the variability in the magnitude of the local stratospheric ozone fluxes, but, as Liu et al. (2009) pointed out, that the mean differences in ozone abundances in the tropical middle troposphere simulated with the two schemes are within $3 \%$.

Tracer advection is computed every $15 \mathrm{~min}$ with a fluxform semi-Lagrangian method (Lin and Rood, 1996). Tracer moist convection is computed using the GEOS convective, entrainment, and detrainment mass fluxes as described by Allen et al. (1996a, b). The deep convection scheme of GEOS-4 is based on Zhang and McFarlane (1995), and the shallow convection treatment follows Hack (1994). GEOS5 convection is parameterized using the relaxed ArakawaSchubert scheme (Moorthi and Suarez, 1992).

Emissions of lightning $\mathrm{NO}_{\mathrm{x}}$ in GEOS-Chem are computed locally in deep convection events following the scheme of Price and Rind (1992) that relates flash rates to convective cloud top heights. The $\mathrm{NO}_{\mathrm{x}}$ emissions are vertically distributed following the profile from Pickering et al. (1998) where $55-75 \%$ of the emissions are above $8 \mathrm{~km}$. Implementation of the lightning source in GEOS-Chem is as described by Wang et al. (1998) with some recent updates (Hudman et al., 2007; Sauvage et al., 2007; Nassar et al., 2009; Jourdain et al., 2010; Murray et al., 2012). The model also includes two alternative lightning schemes that link flash rates to either convective precipitation or upward convective mass flux, following Allen and Pickering (2002). The lightning modules as implemented in GEOS-Chem based on the aforementioned three schemes are hereafter referred to as $\mathrm{CTH}$, PREC, and MFLUX, respectively. To improve the spatial distribution of lightning in the model, the spatial distribution of lightning is scaled to reproduce seasonal mean lightning flash rates to match the climatological satellite observations of lightning flashes from the Optical Transient Detector and Lightning Imaging Sensor (OTD/LIS) High Resolution Monthly Climatology (HRMC) v2.2 product (Christian et al., 2003). Globally the lightning $\mathrm{NO}_{\mathrm{x}}$ source is scaled to $6 \mathrm{Tg} \mathrm{N}$ $\mathrm{yr}^{-1}$ (Martin et al., 2007; Hudman et al., 2007; Sauvage et al., 2007).

Lightning flash rates in global atmospheric models are usually parameterized from functions of proxies of deep convection, enabling the linking of lightning $\mathrm{NO}_{\mathrm{x}}$ emissions with the concurrent convective transport of surface precursors. We test here those based on convective cloud top heights (CTH) (Price and Rind, 1992, 1993, 1994), upward convective mass flux (MFLUX) (Allen et al., 2000), and total convective precipitation (PREC) (Allen and Pickering, 2002) using 6-h mean archived meteorology from the Goddard Earth Observing System Data Assimilation System (GEOS DAS) version 5.1.0. Once the flash rate is determined for a grid box, a $\mathrm{NO}_{\mathrm{x}}$ per flash yield is applied, and the $\mathrm{NO}_{\mathrm{x}}$ emissions are vertically distributed throughout the column following the probability distribution functions of Pickering et al. (1998). The CTH parameterization was originally implemented by Wang et al. (1998) and MFLUX and PREC by
Murray et al. (2012). Each parameterization shows little skill in matching the spatial and seasonal distribution of flash rates observed in the long-term mean Lightning Imaging Sensor and Optical Transient Detector (LIS/OTD) High Resolution Monthly Climatology (HRMC) v2.2 satellite product, and therefore techniques have been variously implemented to constrain the flash rates derived from the GEOS met fields (e.g., Sauvage et al., 2007; Jourdain et al., 2010; Allen et al., 2010; Murray et al., 2012). We also use here an optional "local redistribution" as implemented by Murray et al. (2012). It applies a local seasonal rescaling factor based on spacebased observations of lightning flash counts from the multiyear seasonally varying climatological lightning flashes from HRMC product to constrain GEOS-Chem lightning flashes (Sauvage et al., 2007; Murray et al., 2012). Due to the lack of GEOS-5 meteorological fields during the observation period of the HRMC product (May 1995 through December 2005), we determine the constraint using the long-term monthly mean from all available months of GEOS v5.1.0 meteorology (January 2004 through August 2008).

Biomass burning emissions are long known to be a key factor influencing tropical tropospheric $\mathrm{O}_{3}$ (Fishman et al., 1990; Jacob et al., 1996; Thompson et al., 1996). Biomass burning emissions in the present study are from GFED v2 that resolves the interannual variability of biomass burning emissions (van der Werf et al., 2006; Randerson et al., 2006). GFED v2 is derived using satellite observations including active fire counts and burned areas in conjunction with the Carnegie-Ames-Stanford-Approach (CASA) biogeochemical model. Carbon emissions are calculated as the product of burned area, fuel load and combustion completeness. Burned area is derived using the active fire and 500$\mathrm{m}$ burned area datasets from the Moderate Resolution Imaging Spectroradiometer (MODIS) as described by Giglio et al. (2006). The original GFED v2 inventory has a spatial resolution of $1^{\circ}$ (latitude) $\times 1^{\circ}$ (longitude) and a monthly temporal resolution. The emissions are re-sampled to $2^{\circ}$ (latitude) $\times 2.5^{\circ}$ (longitude) grids for use in our GEOS-Chem simulations. Forest fires typically last from several days to weeks as seen in MODIS active fires (Giglio et al., 2003). Therefore, we re-sampled GFED v2 monthly emissions to an 8-day time step according to MODIS 8-day active fire counts (Chen et al., 2009). The GFED v2 8-day emissions are used for the model simulations presented here unless stated otherwise.

The fossil fuel emissions are from the Emission Database for Global Atmospheric Research (EDGAR) inventory for $\mathrm{NO}_{\mathrm{x}}, \mathrm{CO}$, and $\mathrm{SO}_{2}$ (Olivier et al., 2001) and from the Global Emission Inventory Activity (GEIA) for other chemical compounds (Benkovitz et al., 1996) with additional updates as described by Hudman et al. (2007). Asian anthropogenic emissions are updated with the estimates from Zhang et al. (2009). Biofuel emissions are from Yevich and Logan (2003). The biogenic VOCs emissions are based on the 

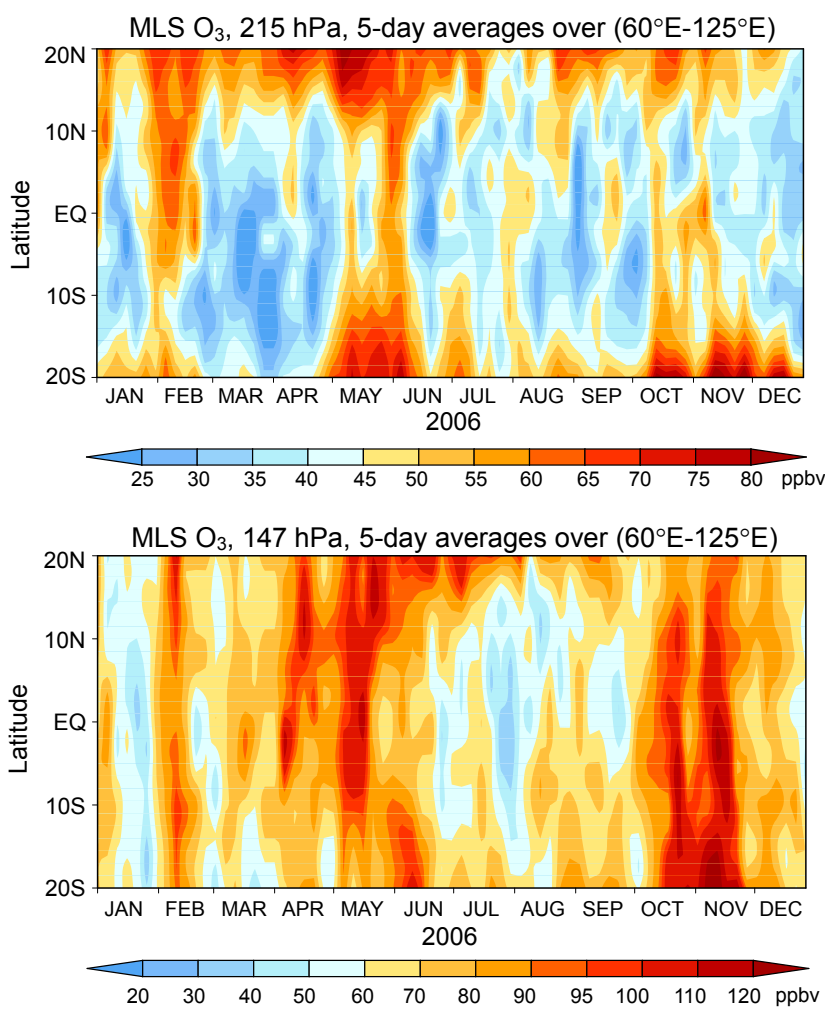

Fig. 3. MLS observed upper tropospheric $\mathrm{O}_{3}$ at (top panel) $215 \mathrm{hPa}$ and (bottom panel) $147 \mathrm{hPa}$ over $20^{\circ} \mathrm{S}-20^{\circ} \mathrm{N}$ for 2006 . Values are 5-day averages over the $60^{\circ} \mathrm{E}-125^{\circ} \mathrm{E}$ longitudes.

Model of Emissions of Gases and Aerosols from Nature (MEGAN) inventory (Guenther et al., 2006).

We conducted model simulations from 2005 to 2009 driven by either GEOS-4 or GEOS-5 meteorological data. We calculated the TCO by integrating the simulated $\mathrm{O}_{3}$ vertical profiles up to the tropopause as provided in the GEOS meteorological fields. The tropopause in GEOS is defined as the pressure where the function $a T(p)-\log _{10} p(\alpha=0.03$, $T$ is temperature and $\mathrm{p}$ is pressure) reaches its first minimum above the surface, and it varies at each dynamic time step of the model (Rienecker, 2008). The tropopause pressures in GEOS-4 and GEOS-5 are approximately the same to each other in tropics (Zhang et al., 2011). In the comparisons between observations and model results, we applied the same spatial and temporal averaging. Our analysis focuses on the results for 2006. For the comparisons of model results based on different meteorological fields and lighting parameterizations, the details for these simulations are summarized in Table 1. Justifications for these simulations are provided in Sect. 5.

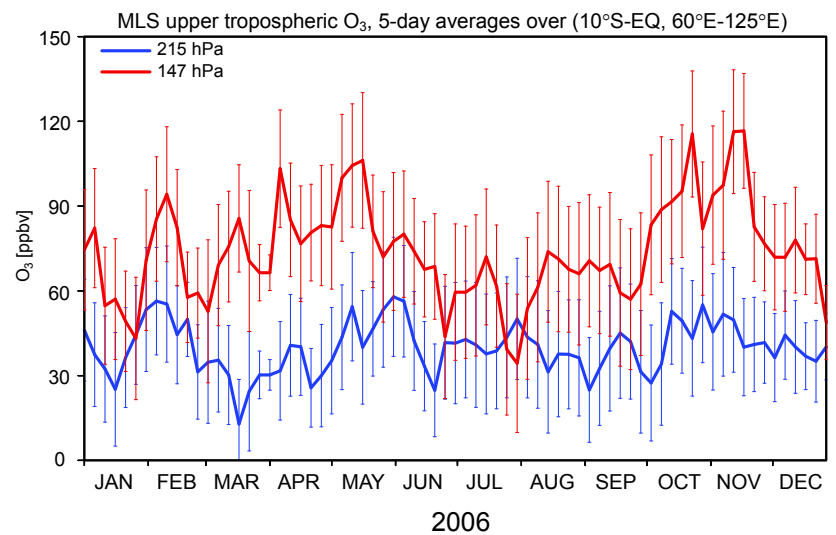

Fig. 4. $\mathrm{MLS}_{3}$ at 147 (red line) and $215 \mathrm{hPa}$ (blue line), averaged over the Equatorial Southern Indian Ocean (see Fig. 1) for 2006. Values are 5-day averages. Vertical bars indicate standard deviations of the measurements.

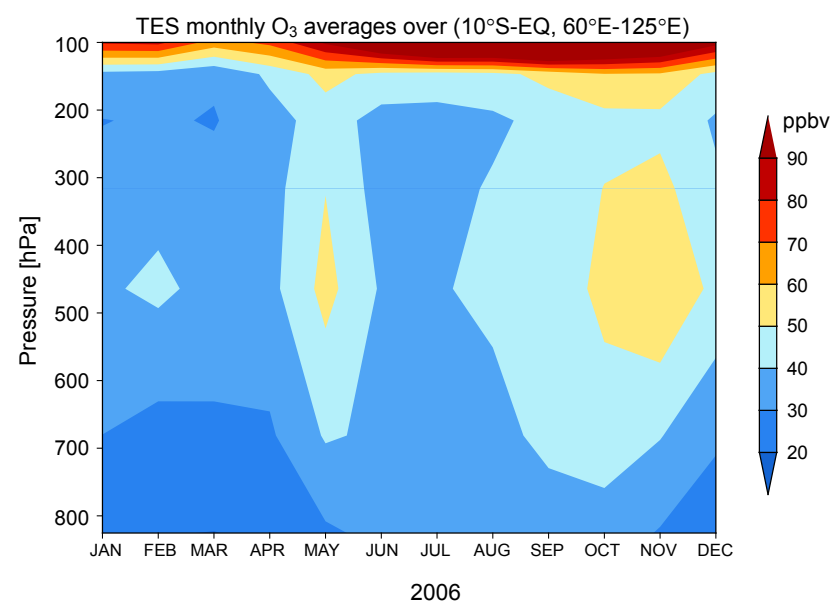

Fig. 5. TES tropospheric $\mathrm{O}_{3}$ vertical distribution averaged over the Equatorial Southern Indian Ocean (see Fig. 1). Values are monthly means for 2006.

\section{Seasonal variation of tropospheric $\mathrm{O}_{3}$ over the ESIO}

\subsection{MLS upper tropospheric $\mathrm{O}_{3}$}

Figure 3 shows $\mathrm{MLS} \mathrm{O}_{3}$ concentrations at $20^{\circ} \mathrm{S}-20^{\circ} \mathrm{N}$, averaged between $60^{\circ} \mathrm{E}$ and $125^{\circ} \mathrm{E}$ for 2006 . The values are 5day averages. South of the equator at $215 \mathrm{hPa}$ the $\mathrm{O}_{3}$ concentrations show a broad maximum during May and early June when the concentrations are higher by 20 to $30 \mathrm{ppbv}$ relative to those during March and April. This maximum is the focus of the present study. There is a secondary peak during late June and early July with maximum concentrations confined to the region between $10^{\circ} \mathrm{S}$ and $20^{\circ} \mathrm{S}$ latitudes. Similar yet considerably enhancements are also evident at $147 \mathrm{hPa}$ during May and June and larger than those at $215 \mathrm{hPa}$. The $\mathrm{O}_{3}$ enhancements during October and November, seen at both 215 and $147 \mathrm{hPa}$, are largely because of the extensive fires 
Table 1. Description of model simulations.

\begin{tabular}{cccl}
\hline Experiment & Year & Meteorological data & Lightning parameterization \\
\hline A1 & 2006 & GEOS-4 & Convective cloud-top-height \\
A2 & 2006 & GEOS-4 & Convective cloud-top-height with local redistribution \\
A3 & 2006 & GEOS-4 & Convective mass flux \\
A4 & 2006 & GEOS-4 & Convective precipitation \\
B1 & 2006 & GEOS-5 & Convective cloud-top-height \\
B2 & 2006 & GEOS-5 & Convective cloud-top-height with local redistribution \\
\hline
\end{tabular}

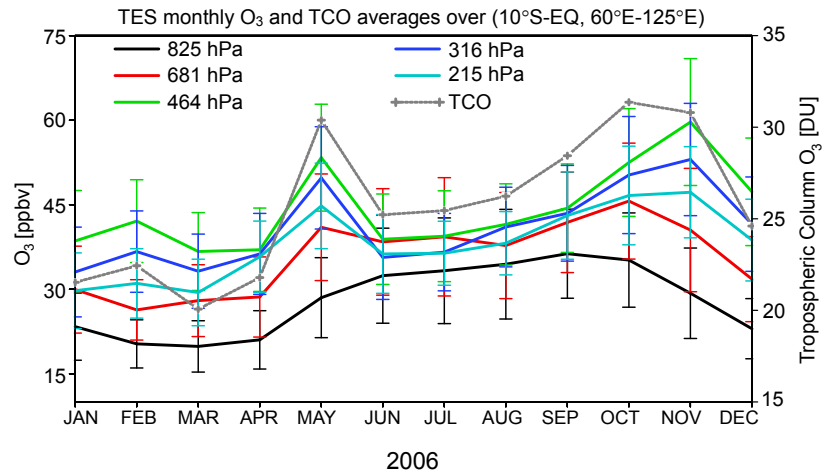

Fig. 6. TES tropospheric $\mathrm{O}_{3}$ and tropospheric column $\mathrm{O}_{3}$ (TCO) over the Equatorial Southern Indian Ocean (see Fig. 1). Values are monthly means for 2006. Vertical bars indicate standard deviations of the measurements.

in Equatorial Asia (mostly in southern Borneo and Sumatra) that lasted from September through November 2006 and the dynamic changes pertained to the $2006 \mathrm{El}$ Niño (Zhang et al., 2011, and references therein). Figure 4 shows time series of $\mathrm{MLS}_{3}$ at 215 and $147 \mathrm{hPa}$ averaged over the entire ESIO domain (Fig. 1) for 2006. Again, broad enhancements of $\mathrm{O}_{3}$ are evident during May-June with maximum $\mathrm{O}_{3}$ concentrations exceeding $55 \mathrm{ppbv}$ at $215 \mathrm{hPa}$ and $100 \mathrm{ppbv}$ at $147 \mathrm{hPa}$.

\subsection{TES middle and upper tropospheric $\mathrm{O}_{3}$}

TES tropospheric $\mathrm{O}_{3}$ also shows a distinct maximum in May 2006 over the ESIO, and the enhancement extends throughout the middle and upper troposphere with peak values above $50 \mathrm{ppbv}$ (Fig. 5). The pronounced and broad $\mathrm{O}_{3}$ enhancements in the middle and upper troposphere during September through December are largely because of the 2006 Indonesian fires in Equatorial Asia (Logan et al., 2008; Nassar et al., 2009; Zhang et al., 2011). Figure 6 shows TES monthly tropospheric $\mathrm{O}_{3}$ and TCO over the ESIO for 2006. Both tropospheric $\mathrm{O}_{3}$ and TCO show seasonal maxima in May and during September through November. The largest $\mathrm{O}_{3}$ enhancements in May are in the middle to upper troposphere, with peak mixing ratios over $50 \mathrm{ppbv}$ at $464 \mathrm{hPa}$. The peak values of TES TCO are over 30 DU in May and in October and November.

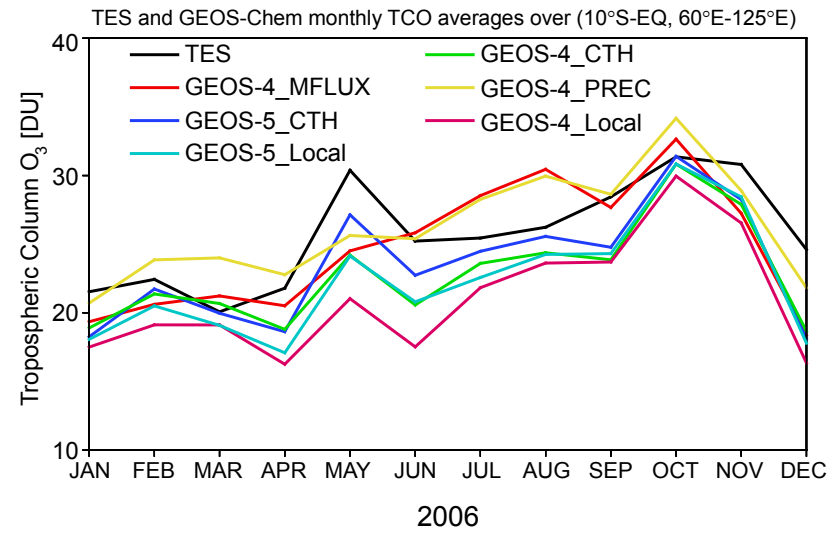

Fig. 7. TES retrieved and GEOS-Chem simulated monthly mean tropospheric column $\mathrm{O}_{3}$ (TCO) for 2006 over the Equatorial Southern Indian Ocean (see Fig. 1). Model results from simulations driven by GEOS-4 and by GEOS-5 reanalysis data and with different lightning parameterizations are shown. See text for more detail.

\section{Lightning impact on tropospheric $\mathrm{O}_{3}$ over the ESIO}

\subsection{Sensitivity to lightning parameterization}

GEOS-Chem simulations of tropospheric $\mathrm{O}_{3}$ have significant dependence on the differences of the lightning parameterizations and the meteorological data used. To examine this sensitivity, we conducted six sensitivity simulations (summarized in Table 1), driven by GEOS-4 or GEOS-5 meteorological data, using the different lightning parameterizations (see Sect. 3). Model TCO averaged over the ESIO are compared against TES data and shown in Fig. 7. For direct comparison to the observations, we calculated monthly mean TCO averages over EISO from model results and TES observations. In general, when comparing TES profiles with other measurements, it is essential to take into account the different sensitivities of the instruments by applying TES averaging kernels (Luo et al., 2007; Worden et al., 2007). However, comparing columns rather than individual profiles significantly reduces the error due to averaging over pressure ranges larger than the TES vertical resolution, $1.5 \%$ for $\mathrm{O}_{3}$ columns averages as compared to $16.5 \%$ for the average profile error between the surface and $35 \mathrm{~km}$ altitude (Osterman et al., 2008). As such, we did not convolve TES averaging kernels with 


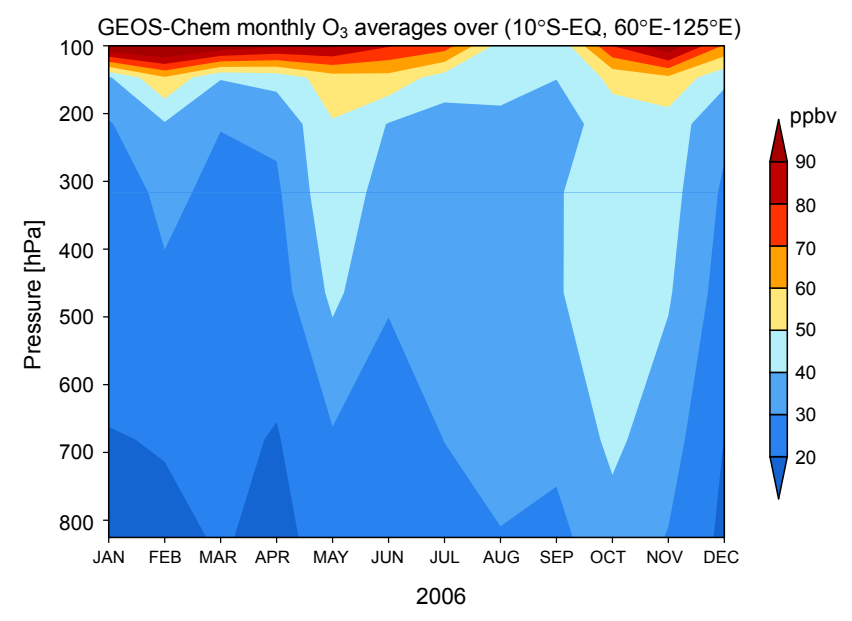

Fig. 8. GEOS-Chem simulated tropospheric $\mathrm{O}_{3}$ vertical distribution averaged over the Equatorial Southern Indian Ocean (see Fig. 1). Values are monthly means for 2006.

GEOS-Chem simulated $\mathrm{O}_{3}$ profiles when calculating model TCOs.

Model simulations A1-A4 were driven by GEOS-4 meteorological data. A1 and A2 used the same CTH lightning parameterization, but $\mathrm{A} 2$ used the local redistribution of lightning flash rates based on LIS/OTD observations (Sect. 3) while A1 did not. A3 and A4 used the MFLUX and the PREC lightning parameterizations, respectively, and neither included the local redistribution factors. Given the way lightning is linked to deep convection in the model, the different deep convection parameterizations used in GEOS-4 and GEOS-5 will also lead to differences in the lightning $\mathrm{NO}_{\mathrm{x}}$ emissions in the model. To examine this sensitivity, we conducted two additional simulations driven by GEOS-5 meteorological data, B1 and B2. Other than the GEOS-5 meteorological data used, $\mathrm{B} 1$ and $\mathrm{B} 2$ mirror $\mathrm{A} 1$ and $\mathrm{A} 2$, respectively.

Figure 7 shows that B1, driven by GEOS- 5 data and with the CTH lightning parameterization, best captures the seasonal variation of TES TCO, including the enhancement in May 2006. Model results are consistently lower than the observations by up to $4 \mathrm{DU}$ for all months. That is not a systematic bias necessarily because TES TCOs are known to be biased high by $\sim 4 \mathrm{DU}$ in comparison with ozonesonde data (Osterman et al., 2008). A1, driven by GEOS-4 data and with the CTH lightning parameterization, significantly underestimates the TCO throughout the year. A3 and A4, driven by GEOS-4 data and with the MFLUX and the PREC lightning parameterizations, show no apparent relative enhancements of TCO in May 2006. Neither reproduces the observed TCO seasonal variation. A2 and $\mathrm{B} 2$, using a local redistribution factor of lightning flash rates based on LIS/OTD data, show no obvious improvements to A1 and B1. In fact, both A2 and B2 show substantially lower TCOs in comparison with not only A1 and B1, respectively, but also TES observations. Therefore, we choose B1 set up as our standard simulation:

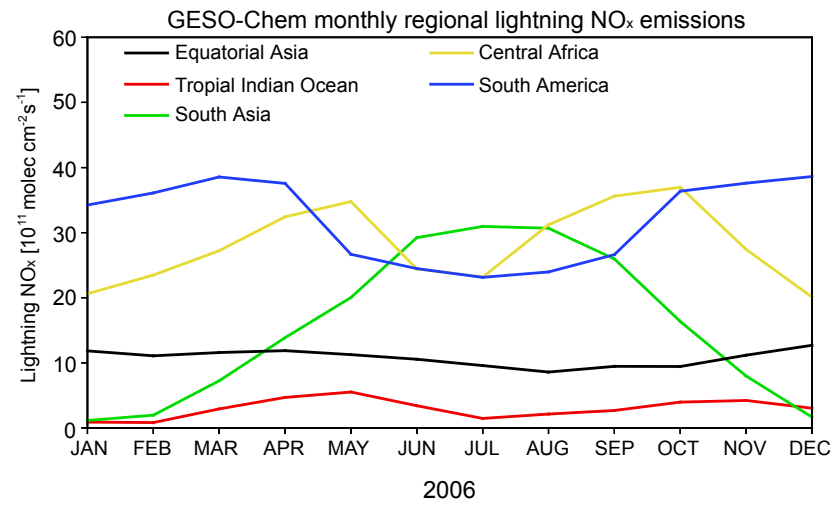

Fig. 9. GEOS-Chem simulated lightning $\mathrm{NO}_{\mathrm{x}}$ emissions over Equatorial Asia (black line), Central Africa (yellow line), South America (blue line), South Asia, and the tropical Indian Ocean (red line). Values are monthly means for 2006. See Fig. 1 for domain definitions.

GEOS-Chem simulation driven by GEOS-5 meteorological data using the $\mathrm{CTH}$ lightning parameterization without local redistribution factor for flash rates. And all the following analyses are based on the B1 set up.

Figure 8 shows the simulated tropospheric $\mathrm{O}_{3}$ in May 2006 over the ESIO by using the above set up. Model reproduces the two enhancements (May and October) extend throughout the middle and upper troposphere as the TES observation, though it underestimates the maximum $\mathrm{O}_{3}$ concentration in the middle troposphere with peak values above $40 \mathrm{ppbv}$ (Fig. 8). The horizontal distributions of tropospheric $\mathrm{O}_{3}$ and TCO are compared between GEOS-Chem and satellite observations (figures are not shown here). The values of TES and GEOS-Chem TCO is about 15 25 DU in April 2006 over the equatorial areas from $60^{\circ} \mathrm{E}$ to the eastern Pacific Ocean. The TCO suddenly increases nearly 10 DU in May over the EISO, while decreases from June. GEOS-Chem underestimates about 4 5 DU in May compared to TES observation over the Indonesian regions and equatorial areas of Asia. The simulated upper tropospheric $\mathrm{O}_{3}$ is lower than that of the MLS in May 2006 over the EISO and surrounding areas.

\subsection{Regional lightning $\mathrm{NO}_{\mathrm{x}}$ emissions in the tropics}

To examine the relative contributions from lightning, we focus our analysis on the following geographical regions (Fig. 1): the tropical Indian Ocean $\left(10^{\circ} \mathrm{S}-10^{\circ} \mathrm{N}, 40^{\circ} \mathrm{E}-\right.$ $\left.95^{\circ} \mathrm{E}\right)$, South Asia $\left(10^{\circ} \mathrm{N}-30^{\circ} \mathrm{N}, 70^{\circ} \mathrm{E}-110^{\circ} \mathrm{E}\right)$, Equatorial Asia $\left(10^{\circ} \mathrm{S}-10^{\circ} \mathrm{N}, 95^{\circ} \mathrm{E}-150^{\circ} \mathrm{E}\right)$, Central Africa $\left(10^{\circ} \mathrm{S}-20^{\circ} \mathrm{N}, 20^{\circ} \mathrm{W}-40^{\circ} \mathrm{E}\right)$ and South America $\left(20^{\circ} \mathrm{S}-\right.$ $15^{\circ} \mathrm{N}, 85^{\circ} \mathrm{W}-35^{\circ} \mathrm{W}$ ). Figure 9 shows the seasonal variations of monthly lightning $\mathrm{NO}_{\mathrm{x}}$ emissions from the aforementioned five regions. Again, these results are from the standard simulation driven by GEOS-5 meteorological data and with the CTH lightning parameterization (simulation B1). 


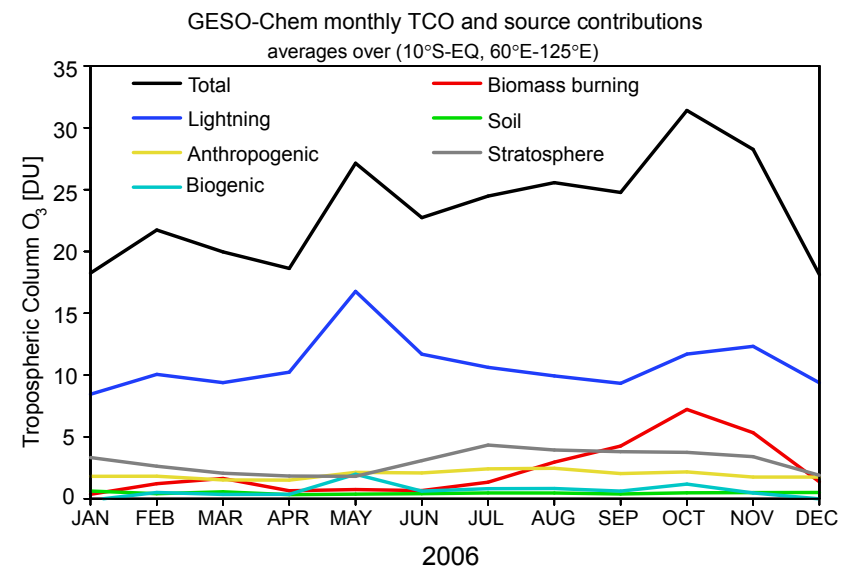

Fig. 10. GEOS-Chem simulated tropospheric column $\mathrm{O}_{3}$ over the Equatorial Southern Indian Ocean (see Fig. 1). Values are monthly means for 2006. Also shown are tropospheric column $\mathrm{O}_{3}$ because of $\mathrm{NO}_{\mathrm{x}}$ emissions from lightning (blue line), biomass burning (red line), soil (green line), stratospheric downward transport (grey line), anthropogenic sources (yellow line), and biogenic sources (cyan line).

The seasonal variations of lightning $\mathrm{NO}_{\mathrm{x}}$ vary considerably among the regions. Lightning $\mathrm{NO}_{\mathrm{x}}$ emissions from South Asia show a broad maximum during June-August, the intense phase of the Asian monsoon with abundant convective activities. Central African lightning $\mathrm{NO}_{\mathrm{x}}$ emissions are largest first in May and then in September-October. Lightning $\mathrm{NO}_{\mathrm{x}}$ emissions from South America show peaks during March through April and then October through December. Equatorial Asia lightning $\mathrm{NO}_{\mathrm{x}}$ emissions show little seasonal variation and are at least a factor of two smaller than those from South Asia, Central Africa and South America. Lightning $\mathrm{NO}_{\mathrm{x}}$ emissions from the tropical Indian Ocean are smallest among the five regions but peak in May. In May, the largest lightning $\mathrm{NO}_{\mathrm{x}}$ emissions are from Central Africa and South America.

\subsection{Lightning contribution to tropospheric $\mathrm{O}_{3}$ over the ESIO}

We conducted several sensitivity simulations for 2006 to quantify the relative contributions to the tropical tropospheric $\mathrm{O}_{3}$ over the ESIO from $\mathrm{NO}_{\mathrm{x}}$ emissions from lightning, biomass burning, soil, stratospheric downward flux, anthropogenic activities and biogenic sources by shutting off these sources individually. The difference between these sensitivity simulations and the standard simulation are thus the contributions from the corresponding sources except the stratospheric downward flux. Here the contribution of the stratospheric downward flux is quantified by the tagged $\mathrm{O}_{3}$ simulation. For tagged $\mathrm{O}_{3}$ analysis, the Synoz scheme can ensure that the source of $\mathrm{O}_{3}$ from the stratosphere would not be overestimated (Liu et al., 2009, 2011), since assimilated meteoro-

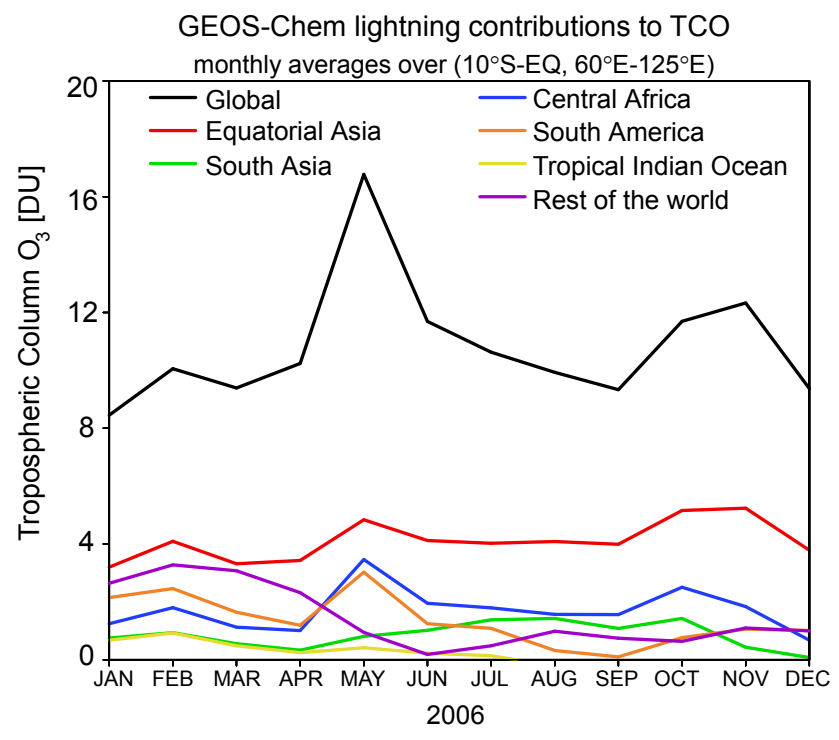

Fig. 11. GEOS-Chem simulated total and lightning tropospheric column $\mathrm{O}_{3}$ over the Equatorial Southern Indian Ocean (see Fig. 1). Lightning $\mathrm{O}_{3}$ refers to $\mathrm{O}_{3}$ produced as a result of lightning $\mathrm{NO}_{\mathrm{x}}$ emissions. Values are monthly means for 2006. Tropospheric column $\mathrm{O}_{3}$ from lightning $\mathrm{NO}_{\mathrm{x}}$ emissions over Equatorial Asia, Central Africa, South America, South Asia, and the tropical Indian Ocean (see Fig. 1) are shown.

logical fields produce excessive stratosphere-to troposphere exchange (Weaver et al., 1993; Tan et al., 2004). Therefore, the cross-tropopause flux of $\mathrm{O}_{3}$ can be matched to observations, which can correctly reproduce the annual global source of stratospheric $\mathrm{O}_{3}$ (McLinden et al., 2000; Liu et al., 2009). Again, all simulations are driven by GEOS- 5 meteorological data and with the $\mathrm{CTH}$ lightning parameterization. The resulting contributions, calculated as monthly TCOs averaged over the ESIO, are shown in Fig. 10.

Lightning contribution is $\sim 10 \mathrm{DU}$ on average for much of the year and peaks in May, accounting for more than $60 \%$ of the total TCO with $17 \mathrm{DU}$, and are directly responsible for the $\mathrm{O}_{3}$ enhancement in May. Biomass burning has a rather small contribution during January to July. The significant biomass burning impact during September to November is associated with the 2006 fires in Equatorial Asia (Logan et al., 2008; Chandra et al., 2009; Nassar et al., 2009; Zhang et al., 2011). Lightning also makes a significant contribution to the September-November enhancement, as seen in Fig. 10 and was discussed in more detail by Zhang et al. (2011). Without any relative enhancement in May, however, stratospheric downward flux merely provides a background to TCO throughout the year. The contributions from soil and anthropogenic activities are negligibly small (less than 2.5 DU) throughout the year, and none of which peaks in May. Though the contribution from biogenic emission has a peak in May, the contribution is considerably smaller, too. 
GEOS-Chem regional lightning contributions to tropospheric $\mathrm{O}_{3}$ averages over $10^{\circ} \mathrm{S}-\mathrm{EQ}$
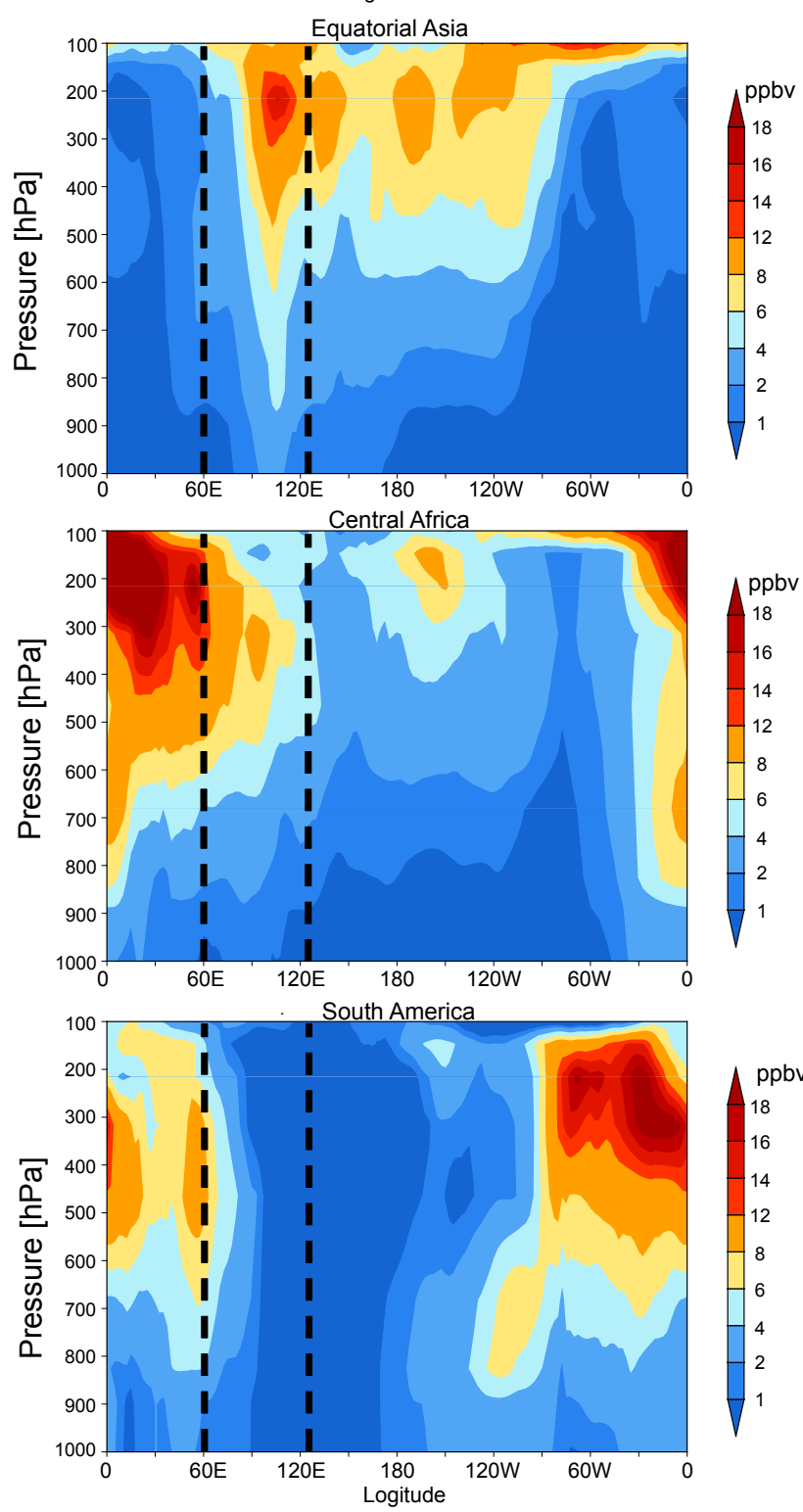

Fig. 12. GEOS-Chem simulated vertical and longitudinal distributions of tropospheric $\mathrm{O}_{3}$ from Lightning $\mathrm{NO}_{\mathrm{x}}$ emissions from (top panel) Equatorial Asia, (middle panel) central Africa, and (bottom panel) South America. Values are monthly means for May 2006, averaged over $10^{\circ} \mathrm{S}$ to the equator.

Several sensitivity simulations were conducted by turning off the lightning $\mathrm{NO}_{\mathrm{x}}$ emission from different sources regions (Fig. 1) to quantify their relative contributions. The difference between these sensitivity simulations and the standard simulation are thus the lightning $\mathrm{NO}_{\mathrm{x}}$ contributions from the corresponding sources regions. The relative contributions to the TCO over the ESIO from lightning $\mathrm{NO}_{\mathrm{x}}$ emissions from the five regions (Fig. 1) are shown in Fig. 11 and summarized in Table 2. Lightning $\mathrm{NO}_{\mathrm{x}}$ emissions from
TES and GEOS-Chem monthly TCO, 2005-2009 averages over $\left(10^{\circ} \mathrm{S}-\mathrm{EQ}, 60^{\circ} \mathrm{E}-125^{\circ} \mathrm{E}\right)$

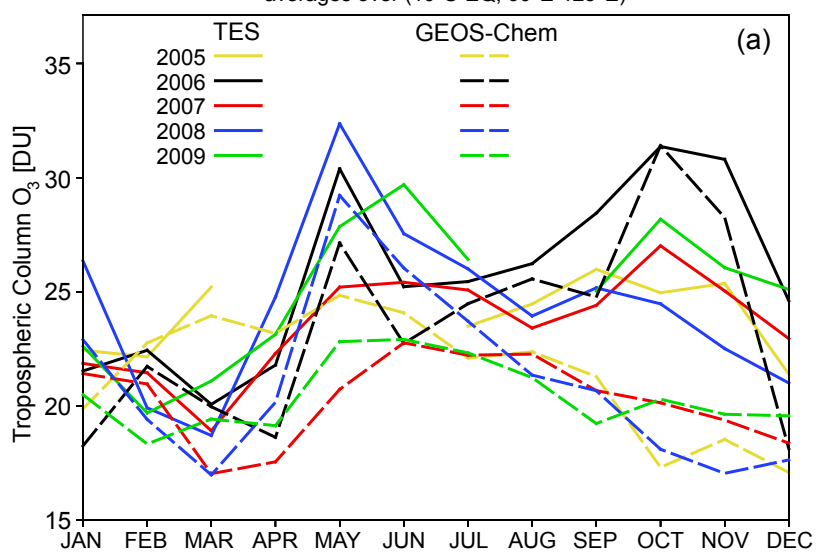

MLS and GEOS-Chem monthly $\mathrm{O}_{3}$ at $215 \mathrm{hPa}, 2005-2009$

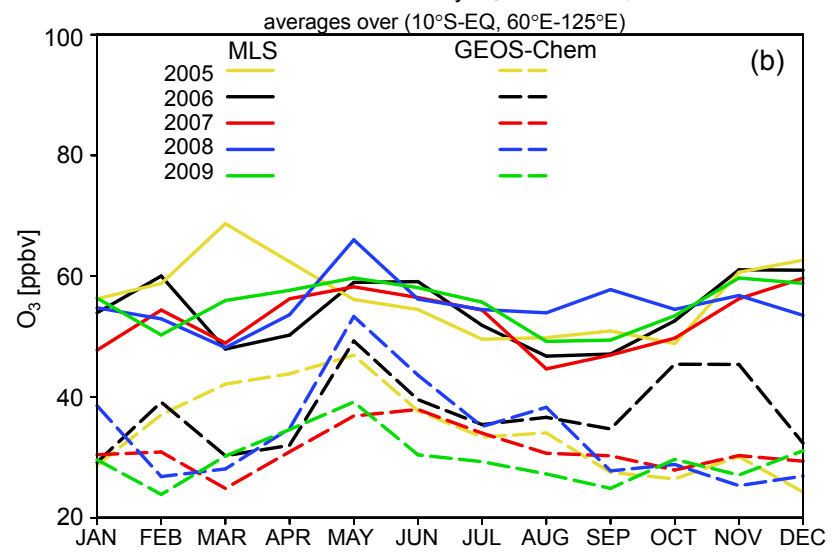

Fig. 13. Observed and simulated tropospheric column $\mathrm{O}_{3}$ (a: TES solid lines; GESO-Chem - dashed lines) and $215 \mathrm{hPa} \mathrm{O} 3$ (b: MLS solid lines; GESO-Chem - dashed lines) over the Equatorial Southern Indian Ocean (see Fig. 1). Values are monthly averages for 2005 to 2009 .

Equatorial Asia contribute $\sim 4$ to $5 \mathrm{DU}$ to TCO from April to December 2006, with relative enhancements in May (29.2\% of the total lightning TCO, i.e., TCO resulting from lightning $\mathrm{NO}_{\mathrm{x}}$ emissions) and October-November. Interestingly and somewhat surprisingly, the contributions to TCO from Central African and South American lightning $\mathrm{NO}_{\mathrm{x}}$ emissions both show sharp peaks in May, $\sim 3.5 \mathrm{DU}$ ( $20.8 \%$ of the total lightning TCO) for Central Africa and 3.0 DU (17.9\% of the total lightning TCO) for South America. We will discuss the lightning outflow from these two regions and its transport to the ESIO in subsequent sections. Figure 11 shows that lightning $\mathrm{NO}_{\mathrm{x}}$ emissions from South Asia make relatively small contributions to the TCO enhancement in May (less than $1 \mathrm{DU}$ or $4.8 \%$ ) and through much of the year, with a slight uptick during the summer months ( $\sim 1$ to $2 \mathrm{DU})$. The contribution from lightning $\mathrm{NO}_{\mathrm{x}}$ emissions from the tropical Indian Ocean is negligibly small (less than $0.5 \mathrm{DU}$ or $2.4 \%$ ) all 
year long. Together, lightning $\mathrm{NO}_{\mathrm{x}}$ emissions from the aforementioned five regions lead to $75.1 \%$ of the total lightning TCO in May 2006 over the ESIO. Lightning $\mathrm{NO}_{\mathrm{x}}$ emissions from the rest of the world contribute $5.4 \%$ (0.9 DU). This contribution is comparable to that from South Asia lightning $\mathrm{NO}_{\mathrm{x}}$ emissions in May and much smaller than those from the Equatorial Asia, Central Africa and South America. Without any relative enhancement in May, however, it decreases from April and merely provides a low background. The lightning $\mathrm{NO}_{\mathrm{x}}$ emissions from the rest of the world contribute less than the remaining to the five sub-domains reflects not only the nonlinearity of $\mathrm{O}_{3}$ production but also the transport impacts. In effect, lightning $\mathrm{NO}_{\mathrm{x}}$ emissions from Equatorial Asia, Central Africa and South America and subsequent $\mathrm{O}_{3}$ production determine the $\mathrm{O}_{3}$ maximum in May 2006. Overall, lightning TCO accounts for $61.8 \%$ of the total TCO over the ESIO in May 2006, of which $18.0 \%, 12.9 \%$, and $11.0 \%$ are because of the lightning $\mathrm{NO}_{\mathrm{x}}$ emissions from Equatorial Asia, Central Africa and South America, respectively (Fig. 11 and Table 2).

Figure 12 shows the modeled vertical and longitudinal distributions of monthly average $\mathrm{O}_{3}$ over $10^{\circ} \mathrm{S}$-equator, resulting from the contributions of lightning $\mathrm{NO}_{\mathrm{x}}$ emissions from Equatorial Asia, Central Africa and South America in May 2006. The $\mathrm{O}_{3}$ mixing ratios are averaged over the latitudinal range of EISO ( $10^{\circ} \mathrm{S}$-equator). The two dashed lines indicate the longitudinal range of the ESIO. There is widespread Equatorial Asian lightning $\mathrm{O}_{3}$ in the middle and upper troposphere over a broad swath between $60^{\circ} \mathrm{E}$ and $60^{\circ} \mathrm{W}$ longitudes, with peak $\mathrm{O}_{3}$ mixing ratios $(\sim 18 \mathrm{ppbv})$ at 150 to $300 \mathrm{hPa}$ over the eastern ESIO (Fig. 12, top panel). These peak $\mathrm{O}_{3}$ mixing ratios from Equatorial Asian lightning $\mathrm{O}_{3}$ contribute directly to the $\mathrm{O}_{3}$ enhancements in the upper tropopause in May (see Figs. 3, 4, 5 and 6). A tongue of Equatorial Asian lightning $\mathrm{O}_{3}$ extends down to the lower troposphere over the eastern ESIO because of intense deep convective activities in that region. Lightning $\mathrm{O}_{3}$ from Central Africa makes a significant contribution to $\mathrm{O}_{3}$ (6 to $12 \mathrm{ppbv}$ ) in the middle and upper troposphere over much of the ESIO, with peak values (12 ppbv) at 200 to $500 \mathrm{hPa}$ over the western ESIO (Fig. 12, middle panel). The contribution from South American lightning $\mathrm{O}_{3}$ (4 to $8 \mathrm{ppbv}$ ) is primarily in the middle to upper troposphere over the western ESIO (Fig. 12, bottom panel).

\section{Interannual variability of tropospheric $\mathrm{O}_{3}$ over the ESIO}

\subsection{Tropospheric $\mathrm{O}_{3}$ over the ESIO from 2005 to 2009}

We investigate in this section the interannual variability of the tropospheric $\mathrm{O}_{3}$ over the ESIO. For this purpose we examined five years (2005 to 2009) of TES TCO and MLS upper tropospheric $\mathrm{O}_{3}$ observations (Fig. 13). Relative en-

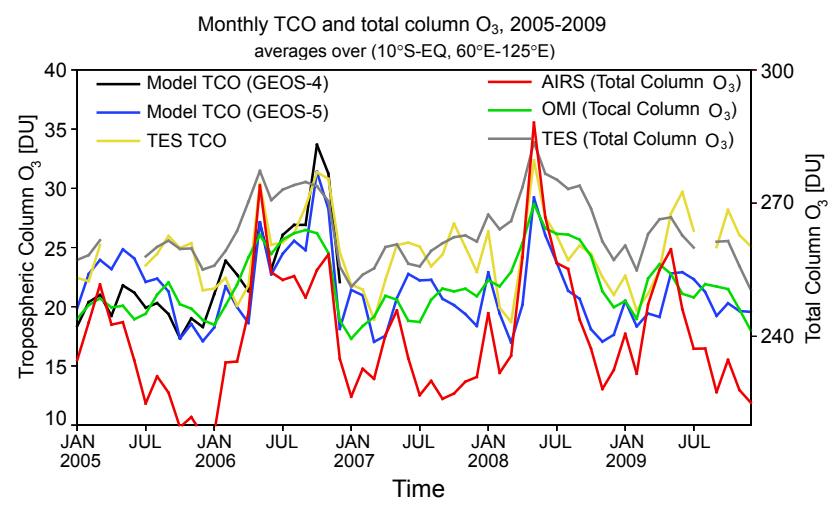

Fig. 14. Monthly mean tropospheric column $\mathrm{O}_{3}$ from GEOS-Chem (black and blue lines) and TES (yellow line) and total column $\mathrm{O}_{3}$ from AIRS (red line), OMI (green line) and TES (grey line) over the Equatorial Southern Indian Ocean (see Fig. 1) for 2005 to 2009. Results from model simulations driven by GEOS-4 (black line) and GEOS-5 (blue) reanalysis data are both shown. See text for more detail.

hancements of TCO are seen in May 2006, 2007, 2008 and 2009 (no TES data for April through June 2005) in both TES observations and model results (Fig. 13a). The enhancements are pronounced and largest in May 2006 and 2008 with TCO values over $30 \mathrm{DU}$. The enhancements in 2007 and 2009 extend from May through July and peak in June. Model results also capture the distinct relative enhancements during October-November 2006 that are related to the 2006 Indonesian fires (Zhang et al., 2011, and references therein) but completely miss those for 2007 and 2009 when model results are vastly lower than the observations in SeptemberDecember. Overall, model simulated TCOs show seasonal variations that are broadly consistent with the observations for 2006 and 2008. Upper tropospheric $\mathrm{O}_{3}$ at $215 \mathrm{hPa}$ also show clear relative enhancements in May 2006 and 2008, both in MLS observations and model results (Fig. 13b). The lightning play an important role in contributing to the upper tropospheric $\mathrm{O}_{3}$ enhancements in May, especially the lightning $\mathrm{NO}_{\mathrm{x}}$ emissions from Equatorial Asia (see Fig. 12). Model results are generally lower by $20 \mathrm{ppbv}$ than the observations, but MLS $\mathrm{O}_{3}$ at $215 \mathrm{hPa}$ is known to have a positive bias of $\sim 20$ ppbv (Livesey et al., 2008, 2011). Model results capture the seasonal cycles of $\mathrm{O}_{3}$ observed by MLS in 2006 but fail to reproduce the enhancements in November and December for other years.

Figure 14 compares GEOS-Chem simulated TCO with TCO from TES and total column $\mathrm{O}_{3}$ from AIRS, OMI and TES. Model results from two simulations driven by GEOS-4 (2005 to 2006) and by GEOS-5 (2005 to 2009) meteorological data are shown. There are considerable differences among the total column $\mathrm{O}_{3}$ from the three satellite data sets. The interannual variability of $\mathrm{OMI}$ total column $\mathrm{O}_{3}$ correlates very well with that of TES, but much lower than TES. This has also been pointed out by previous study that TES is higher 
Table 2. GEOS-Chem simulated total and lightning tropospheric column $\mathrm{O}_{3}$ over the Equatorial Southern Indian Ocean (see Fig. 1). Values are monthly averages for May 2006.

\begin{tabular}{cccccc}
\hline \multicolumn{7}{c}{ Monthly total TCO over ESIO = 27.2 [DU], May 2006 } \\
\hline \multicolumn{7}{c}{ Total lightning contribution = 16.8 [DU] $(61.8 \%)$} \\
\hline \multicolumn{6}{c}{ Regional lightning contribution } \\
\hline Equatorial Asia & Central Africa & South America & South Asia & Tropical Indian Ocean & Rest of the world \\
\hline $4.9[\mathrm{DU}](18.0 \%)$ & $3.5[\mathrm{DU}](12.9 \%)$ & $3.0[\mathrm{DU}](11.0 \%)$ & $0.8[\mathrm{DU}](3.0 \%)$ & $0.4[\mathrm{DU}](1.5 \%)$ & $0.9[\mathrm{DU}](3.3 \%)$ \\
\hline & Percentage of total lightning contribution from regional lightning & \\
\hline $29.2 \%$ & $20.8 \%$ & $17.9 \%$ & $4.8 \%$ & $2.4 \%$ & $5.4 \%$ \\
\hline
\end{tabular}
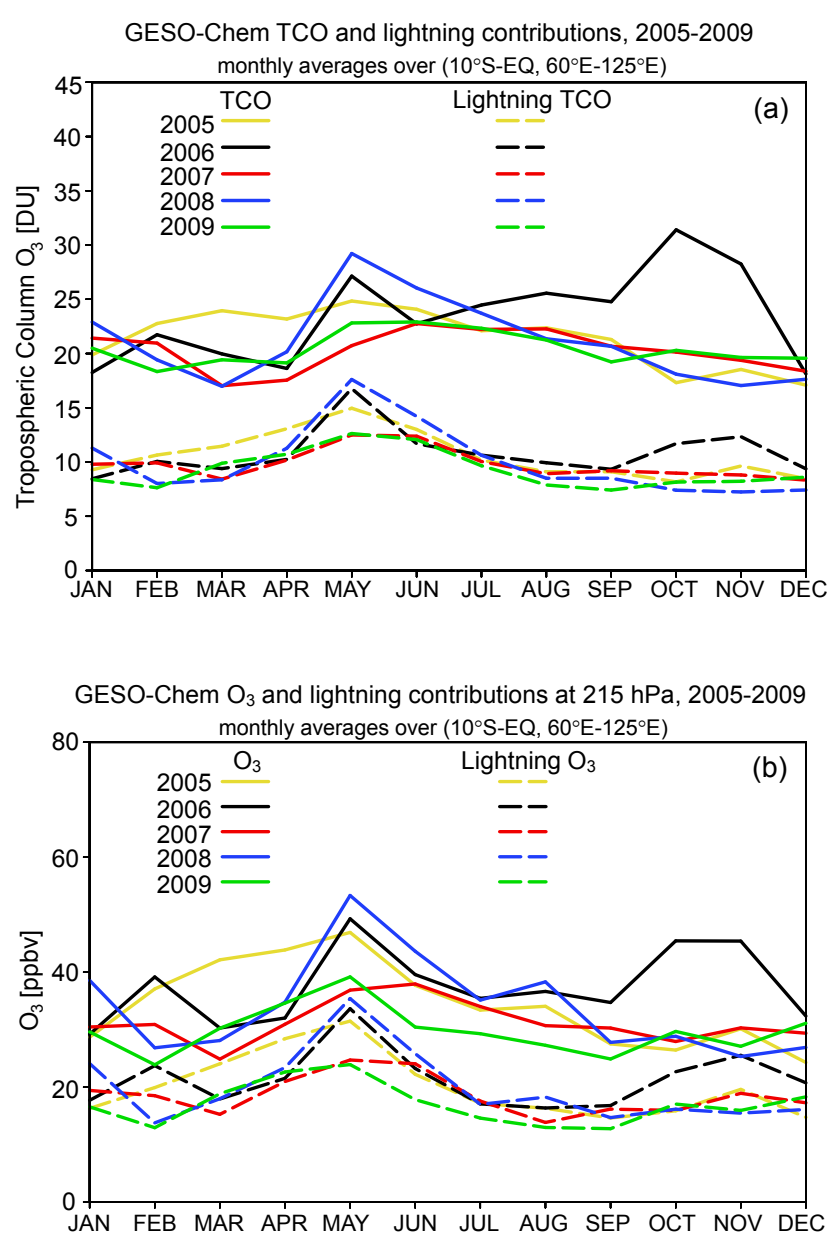

Fig. 15. GEOS-Chem simulated (a) total and lightning tropospheric column $\mathrm{O}_{3}$ and (b) $215 \mathrm{hPa}$ total and lightning $\mathrm{O}_{3}$ over the Equatorial Southern Indian Ocean (see Fig. 1). Lightning $\mathrm{O}_{3}$ refers to $\mathrm{O}_{3}$ produced as a result of lightning $\mathrm{NO}_{\mathrm{x}}$ emissions. Values are monthly means for 2005 to 2009 .

than OMI by $10 \mathrm{DU}$ for the total column $\mathrm{O}_{3}$ (Osterman et al., 2008). Most of the temporal variations of AIRS total column $\mathrm{O}_{3}$ also follow those of TES and OMI. Other than the

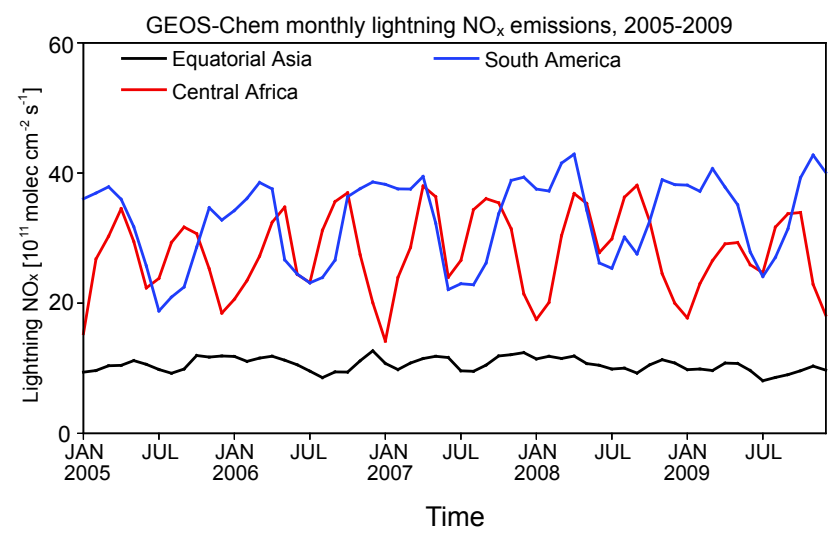

Fig. 16. GEOS-Chem simulated lightning $\mathrm{NO}_{\mathrm{x}}$ emissions over Equatorial Asia, Central Africa, and South America (see Fig. 1). Values are monthly means for 2005 to 2009.

enhanced total column $\mathrm{O}_{3}$ periods, AIRS total column $\mathrm{O}_{3}$ is much lower than those of TES and OMI during most of the periods. These differences may be due to sampling bias (e.g., AIRS am but TES/OMI pm). Our comparison between GEOS-Chem TCO and the satellite observed total column $\mathrm{O}_{3}$ is qualitative rather than quantitative, and we focus on the temporal variability of $\mathrm{O}_{3}$. Robust $\mathrm{TCO}$ and total column $\mathrm{O}_{3}$ enhancements are seen in every May from 2005 to 2009 in both the observations and model results. Again, the observed total column $\mathrm{O}_{3}$ enhancements are most distinct in May of 2006 and 2008 in AIRS, TES and OMI observations. The large $\mathrm{O}_{3}$ enhancements during September-November 2006 are associated with the 2006 Indonesian fires (Logan et al., 2008; Chandra et al., 2009; Nassar et al., 2009; Zhang et al., 2011). Model simulations driven by GEOS-5 reanalysis reproduce the observed enhancements and the interannual variability.

\subsection{Interannual variability of lightning $\mathrm{O}_{3}$}

We conducted model sensitivity simulations driven by GEOS-5 meteorological data for 2005-2009 to quantify the 

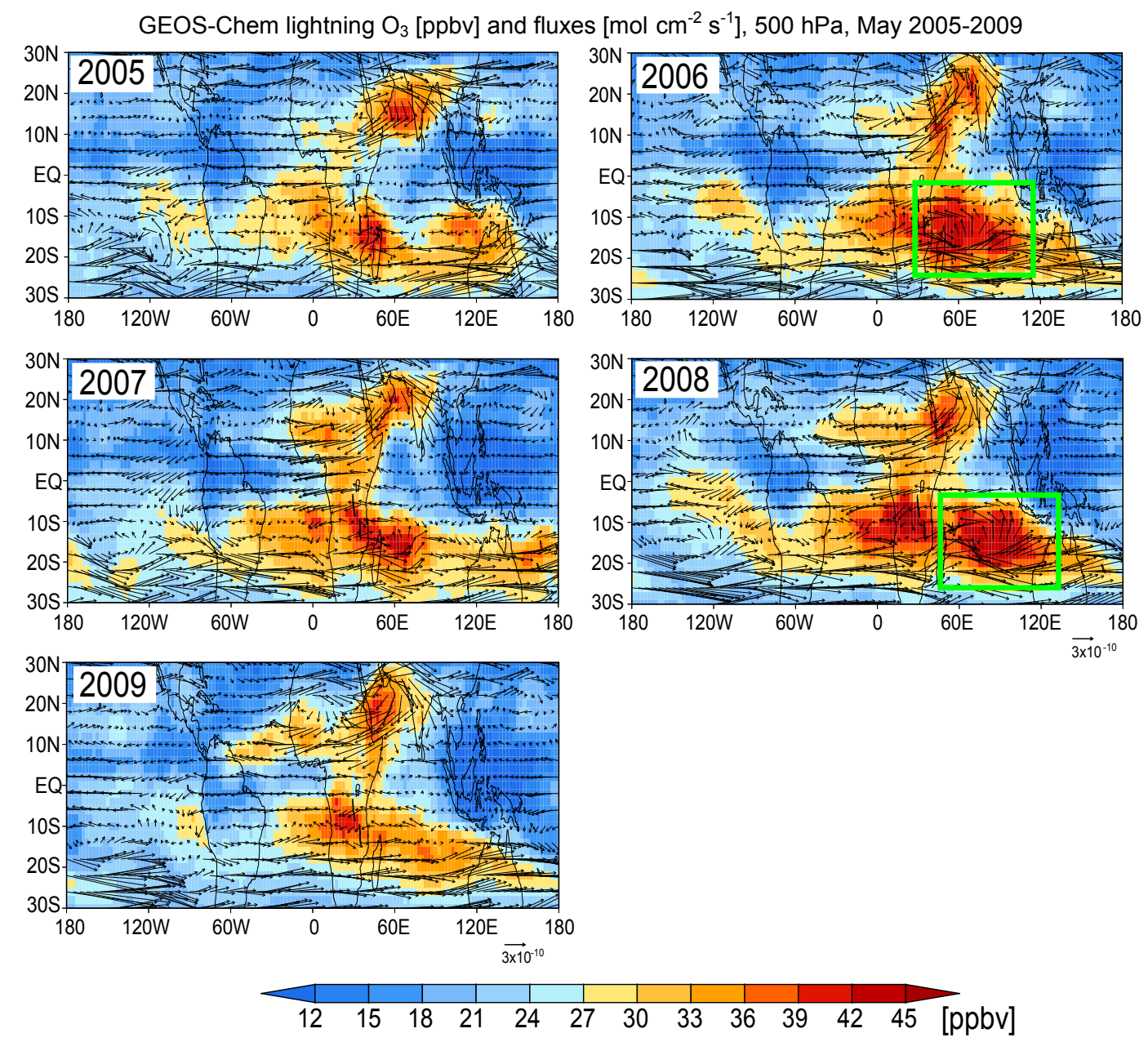

Fig. 17. GEOS-Chem simulated lightning $\mathrm{O}_{3}$ concentrations (color contours, ppbv) and horizontal fluxes (arrows, $\mathrm{mol} \mathrm{cm}^{-2} \mathrm{~s}^{-1}$ ) at $500 \mathrm{hPa}$. Lightning $\mathrm{O}_{3}$ refers to $\mathrm{O}_{3}$ produced as a result of lightning $\mathrm{NO}_{\mathrm{x}}$ emissions. Values are monthly means for May 2005 through 2009 . Rectangles indicate regions of anomalous anti-cyclones.

interannual lightning contributions to tropospheric $\mathrm{O}_{3}$ over the ESIO by turning off lightning $\mathrm{NO}_{\mathrm{x}}$ emissions. The results of total and lighting TCO and $215 \mathrm{hPa} \mathrm{O}_{3}$ are shown in Fig. 15. Lightning $\mathrm{NO}_{\mathrm{x}}$ emissions contribute to the peaks of $\mathrm{O}_{3}$ in May every year from 2005 to 2009 at $215 \mathrm{hPa}$, which result into the observed $\mathrm{O}_{3}$ enhancements in the upper tropopause in May 2006 (see Figs. 3, 4, 5, 6 and 13b). The largest contributions to TCO are in 2006 and 2008 (Fig. 15a) and to $\mathrm{O}_{3}$ (mixing ratios at $215 \mathrm{hPa}$ are shown) in 2005, 2006 and 2008 (Fig. 15b). Lightning $\mathrm{O}_{3}$ clearly controls the May enhancements. However, there is no apparent interannual variability in the model simulated lightning $\mathrm{NO}_{\mathrm{x}}$ emissions from Equatorial Asia, Central Africa and South America - the emissions are not significantly larger in May 2006 and 2008 than in the other three years (Fig. 16). There are clearly additional factors that drive the interannual variability of the tropospheric $\mathrm{O}_{3}$ maximum in May over the ESIO.

\subsection{Anti-cyclonic circulation of Central African and South American lightning outflow}

We examine in this section the dynamics as a potential factor for determining the interannual variability of the tropospheric $\mathrm{O}_{3}$ maximum in May over the ESIO. The lightning $\mathrm{O}_{3}$ and flux from low troposphere to upper troposphere in May from 2005 to 2009 are investigated. The evident anti-cyclone is only shown in the middle troposphere $(500 \mathrm{hPa})$ over the Southern Indian Ocean in May 2006 and 2008 accompanied with high lightning $\mathrm{O}_{3}$, even though the lightning $\mathrm{O}_{3}$ is much higher in the upper troposphere Fig. 17 shows GEOS-Chem simulated monthly middle tropospheric $(500 \mathrm{hPa})$ lightning $\mathrm{O}_{3}$ and flux in May for 2005 to 2009. In the Southern Hemisphere, high lightning $\mathrm{O}_{3}$ are widespread across the southern tropical Indian and South Atlantic Oceans, southern Africa and northern Australia, along the pathways of lightning outflow from Central Africa and South America. The lightning $\mathrm{O}_{3}$ are much stronger in 2006 

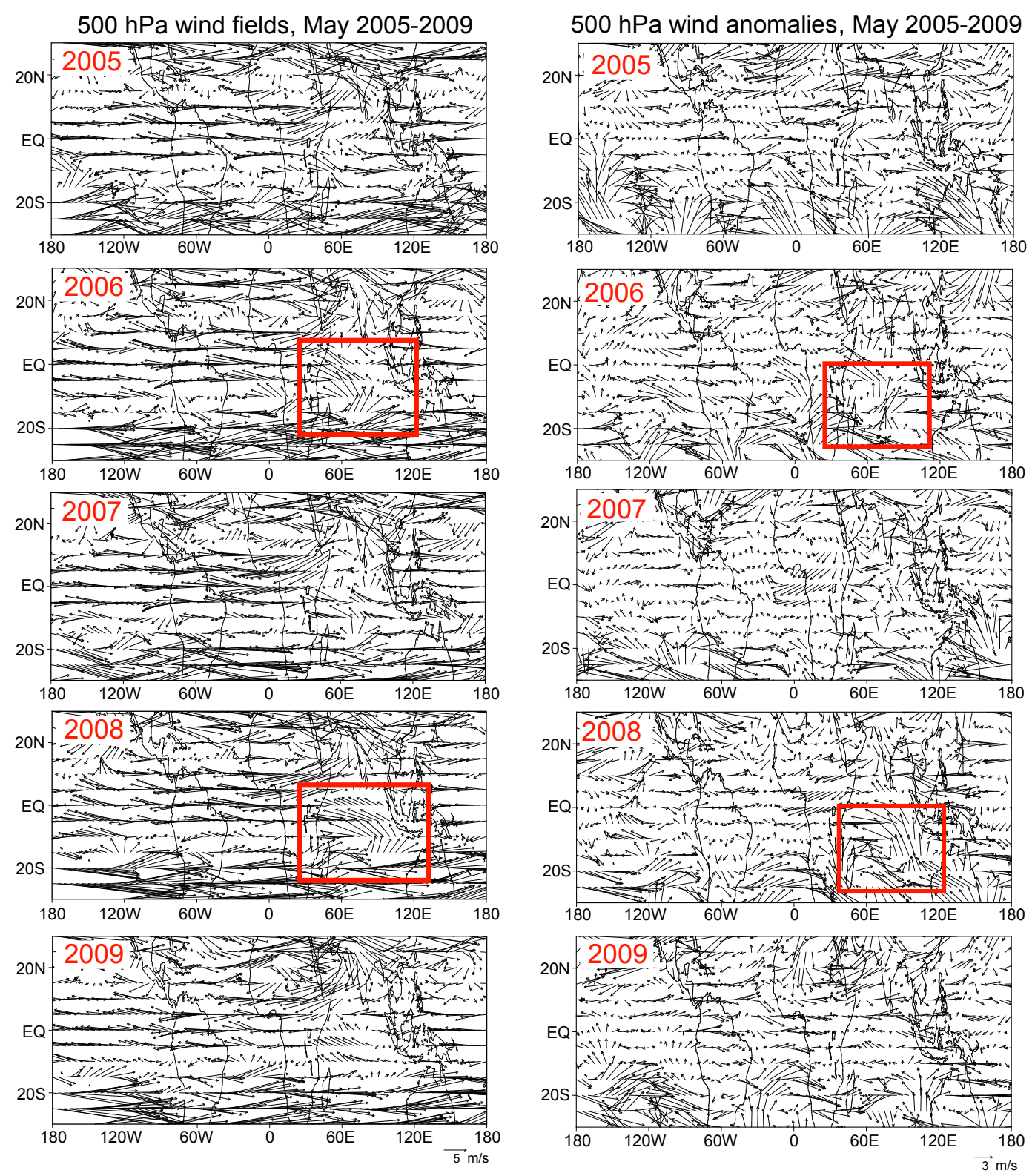

Fig. 18. Monthly mean NCEP wind fields and wind anomalies $\left(\mathrm{m} \mathrm{s}^{-1}\right)$ at $500 \mathrm{hPa}$ for May 2005 through 2009. NCEP reanalysis data provided by the NOAA/OAR/ESRL PSD, Boulder, Colorado, USA, from their web site at http://www.esrl.noaa.gov/psd/. Red rectangles indicate regions of anomalous anti-cyclones.

and 2008 than in 2005, 2008 and 2009. There are strong divergences and northward transport of lightning $\mathrm{O}_{3}$ fluxes over the Southern Indian Ocean in 2006 and 2008. In effect, the anomalous anti-cyclonic circulations in May of 2006 and 2008 effectively entrain and transport $\mathrm{O}_{3}$ in the African and South American lightning outflow to the ESIO. The divergence and northward transport are largely absent in the other three years. Figure 18 shows the $500 \mathrm{hPa}$ wind fields and the wind anomalies based on 40 years (19702009) of climatology from the National Center for Environmental Prediction/National Center for Atmospheric Re- search (NCEP/NCAR) reanalysis (Kalnay et al., 1996). In May 2006 and 2008, the anti-cyclone circulation and strong northward flows are shown in the wind fields over Southern Indian Ocean, which are less evident in the other years (Fig. 18, left panel). From the anomaly analysis of wind fields, anomalous anti-cyclones and southerly winds are evident in May 2006 and 2008, but not in the other three years (Fig. 18, right panel). Figure 19 shows net $\mathrm{O}_{3}$ productions at $500 \mathrm{hPa}$ in May. The net $\mathrm{O}_{3}$ productions are much larger in May 2006 and 2008 than in May 2005, 2007 and 2009. Therefore, the interannual variability of the May $\mathrm{O}_{3}$ 

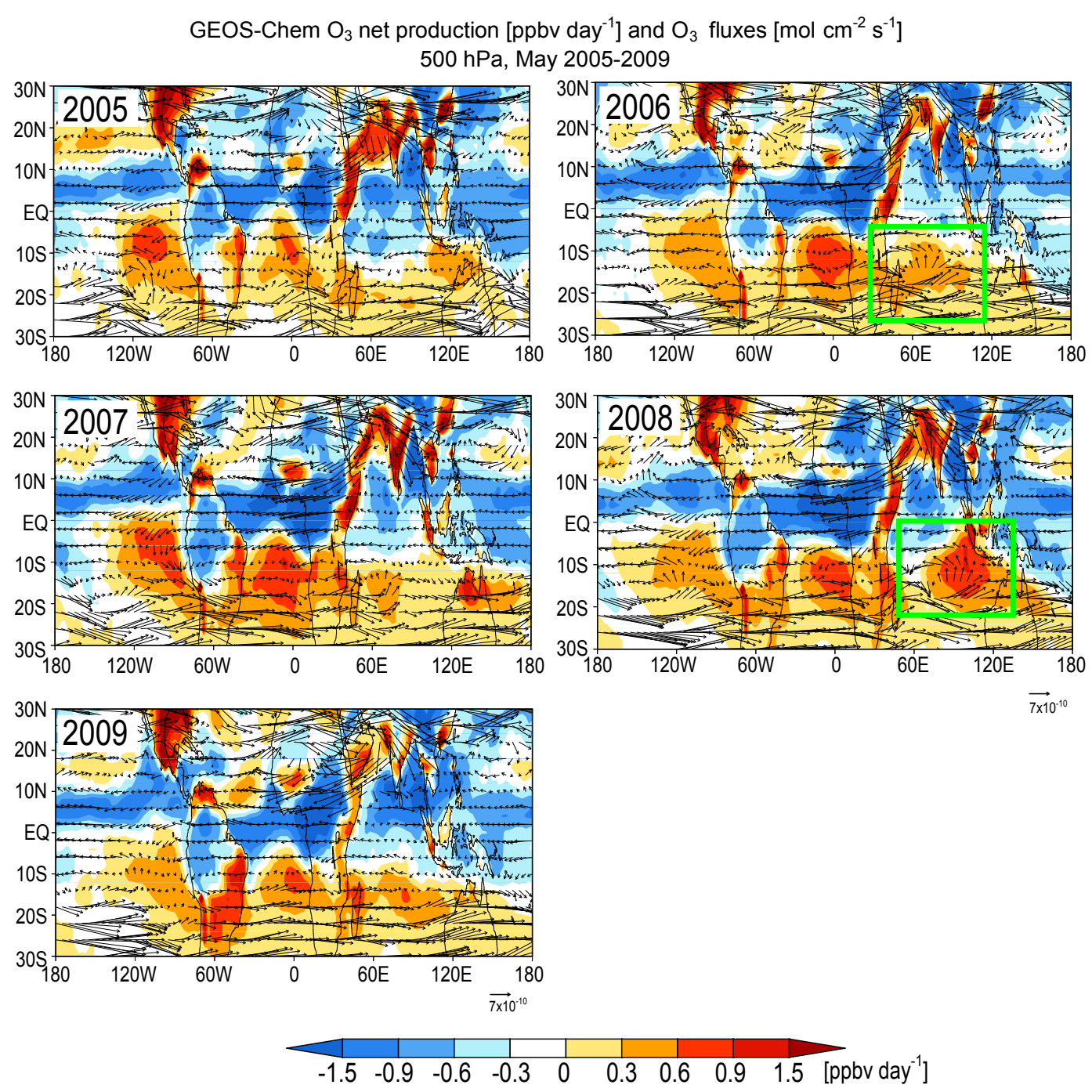

Fig. 19. GEOS-Chem simulated net chemical $\mathrm{O}_{3}$ production rates $\left(\mathrm{ppbv}\right.$ day $\left.{ }^{-1}\right)$ and horizontal $\mathrm{O}_{3}$ fluxes $\left(\operatorname{arrows}, \mathrm{mol} \mathrm{cm}^{-2} \mathrm{~s}^{-1}\right)$ at $500 \mathrm{hPa}$ Values are monthly means for May 2005 through 2009. Rectangles indicate regions of anomalous anti-cyclones.

maximum in middle troposphere is driven largely by the anomalous anti-cyclones over the southern Indian Ocean in May 2006 and 2008. The lightning $\mathrm{NO}_{\mathrm{x}}$ emissions play dominant roles in the upper tropospheric $\mathrm{O}_{3}$ enhancements (see Figs. 12 and 15b) in May 2005, 2006 and 2008 over the southern Indian Ocean. The combined effect of both lightning and dynamic transport in middle and upper troposphere contributes directly to the interannual variability of TCO, with the evident maximum in May 2006 and 2008.

\section{Summary and conclusions}

We analyzed 5-year (2005-2009) tropospheric $\mathrm{O}_{3}$ observations over the Equatorial Southern Indian Ocean (ESIO) from satellite instruments MLS, TES, OMI, and AIRS, using the GEOS-Chem global three-dimensional chemical trans- port model. Model simulated upper tropospheric $\mathrm{O}_{3}$ and tropospheric column $\mathrm{O}_{3}$ (TCO) were compared against the observations. The effects of $\mathrm{NO}_{\mathrm{x}}$ sources from lightning, biomass burning, soil, stratospheric downward transport, anthropogenic and biogenic emissions on the tropospheric $\mathrm{O}_{3}$ over the ESIO, including the seasonal and interannual variability, were examined. In addition, we investigated the effects of dynamics on the interannual variability of tropospheric $\mathrm{O}_{3}$ over the ESIO.

The satellite observations of tropospheric $\mathrm{O}_{3}$ showed significant enhancements over the ESIO in May. The enhancements were evident not only in MLS upper tropospheric $\mathrm{O}_{3}$, TES middle and upper tropospheric $\mathrm{O}_{3}$ and TCO, but also in TES, OMI, and AIRS total column $\mathrm{O}_{3}$. The enhancements were strongest in 2006 and 2008 and less pronounced in 2005, 2007 and 2009. GEOS-Chem simulations driven by GEOS- 5 reanalysis data, with lightning flash rates 
parameterized based upon convective cloud top heights, were able to capture the May $\mathrm{O}_{3}$ enhancements and the associated interannual variability.

We found that lightning contribution accounted for more than $60 \%$ (17 DU) of the total TCO in May 2006, and largely controlled the May $\mathrm{O}_{3}$ enhancement. The lightning contribution was dominated by lightning $\mathrm{NO}_{\mathrm{x}}$ emissions from Equatorial Asia, Central Africa and South America. Equatorial Asian lightning contributed on average $\sim 4$ to $5 \mathrm{DU}(29.2 \%$ of the total lightning TCO) to the TCO from April through December 2006, with clear enhancements in May 2006. The contributions to the TCO from Central African ( 3.5 DU, $20.8 \%)$ and South American ( 3.0 DU, 17.9\%) lightning $\mathrm{NO}_{\mathrm{x}}$ emissions both showed distinct peaks in May 2006. We found that $\mathrm{NO}_{\mathrm{x}}$ emissions from biomass burning, soil, anthropogenic activities and biogenic sources had rather small contributions (less than 2.5 DU) to the tropospheric $\mathrm{O}_{3}$ enhancements in May 2006. The stratospheric downward transport provided a background about $5 \mathrm{DU}$ throughout the year of 2006.

The larger and more distinct enhancements of TCO in May 2006 and 2008 than those in May 2005, 2007, and 2009 were a directly combined result of the anomalous anticyclonic circulations in the middle troposphere and lightning $\mathrm{O}_{3}$ in the upper troposphere over the Southern Indian Ocean, which were much stronger in 2006 and 2008 than in the other three years. The anomalous anti-cyclonic circulation extended to the middle troposphere. The largescale subsidence associated with the anti-cyclones served as a conduit that channeled downward the middle and upper tropospheric lightning outflow from Central Africa and South America. As such, lightning $\mathrm{O}_{3}$ outflows from Central Africa and South America were effectively entrained by the anti-cyclones, followed by northward transport to the ESIO. Therefore, the interannual variability of the tropospheric $\mathrm{O}_{3}$ enhancements over the ESIO was largely driven by these anomalous anti-cyclones over the Southern Indian Ocean.

Acknowledgements. This research was supported in part by NASA grants NNX09AF07G and NNX08AF64G from the Atmospheric Chemistry Modeling and Analysis Program (ACMAP). We also acknowledge supports by the NASA Aura Science Team program. Work at Jet Propulsion Laboratory, California Institute of Technology was done under contract with the National Aeronautics and Space Administration. The GEOS-Chem model is managed by the Atmospheric Chemistry Modeling group at Harvard University with support from the NASA ACMAP program. We thank Jennifer Logan for helpful discussions.

Edited by: M. Kopacz

\section{References}

Allen, D. J. and Pickering, K. E.: Evaluation of lightning flash rate parameterizations for use in a global chemical transport model,
J. Geophys. Res., 107, 4711, doi:10.1029/2002JD002066, 2002.

Allen, D. J., Kasibhatla, P., Thompson, A. M., Rood, R. B., Doddridge, B. G., Pickering, K. E., Hudson, R. D., and Lin, S.-J.: Transport induced interannual variability of carbon monoxide using a chemistry and transport model, J. Geophys. Res., 101, 28655-28670, 1996a.

Allen, D. J., Rood, R. B., Thompson, A. M., and Hidson, R. D.: Three-dimensional $222 \mathrm{Rn}$ calculations using assimilated data and a convective mixing algorithm, J. Geophys. Res., 101, 68716881, 1996 b.

Allen, D. J., Pickering, K. E., Stenchikov, G. L., Thompson, A. M., and Kondo, Y.: A three-dimensional total odd nitrogen (NOy) simulation during SONEX using a stretched-grid chemical transport model, J. Geophys. Res., 105, 3851-3876, 2000.

Allen, D. J., Pickering, K. E., Duncan, B., and Damon, M.: Impact of lightning NO emissions on North American photochemistry as determined using the Global Modeling Initiative (GMI) model, J. Geophys. Res., 115, D22301, doi:10.1029/2010JD014062, 2010.

Aumann, H. H., Chahine, M. T., Gautier, C., Goldberg, M. D., Kalnay, E., McMillin, L. M., Revercomb, H., Rosenkranz, P. W., Smith, W. L., Staelin, D. H., Strow, L. L., and Susskind, J.: AIRS/AMSU/HSB on the Aqua mission: Design, science objectives and data products, IEEE Trans. Geosci. Remote Sens., 41, 253-264, doi:10.1109/TGRS.2002.808356, 2003.

Balis, D., Kroon, M., Koukouli, M. E., Brinksma, E. J., Labow, G., Veefkind, J. P., and McPeters, R. D.: Validation of Ozone Monitoring Instrument total ozone column measurements using Brewer and Dobson spectrophotometer ground-based observations, J. Geophys. Res., 112, D24S46, doi:10.1029/2007JD008796, 2007.

Beer, R.: TES on the Aura mission: Scientific objectives, measurements, and analysis overview, IEEE Trans. Geosci. Remote Sens., 44, 1102-1105, doi:10.1109/TGRS.2005.863716, 2006.

Beer, R., Glavich, T. A., and Rider, D. M.: Tropospheric Emission Spectrometer for the Earth Observing System's Aura satellite, Appl. Optics, 40, 2356-2367, 2001.

Benkovitz, C., Scholtz, M., Pacyna, J., Tarrasón, L., Dignon, J., Voldner, E., Spiro, P., Logan, J., and Graedel, T.: Global gridded inventories of anthropogenic emissions of sulfur and nitrogen, J. Geophys. Res., 101, 29239-29253, 1996.

Bey, I., Jacob, D. J., Yantosca, R. M., Logan, J. A., Field, B. D., Fiore, A. M., Li, Q. B., Liu, H. G. Y., Mickley, L. J., and Schultz, M. G.: Global modeling of tropospheric chemistry with assimilated meteorology: Model description and evaluation, J. Geophys. Res., 106, 23073-23096, 2001.

Bloom, S., Silva, A. da, Dee, D., Bosilovich, M., Chern, J.-D., Pawson, S., Schubert, S., Sienkiewicz, M., Stajner, I., Tan, W.-W., and $\mathrm{Wu}$, M.-L.: Documentation and Validation of the Goddard Earth Observing System (GEOS) Data Assimilation System Version 4, 2005.

Bowman, K. W., Rodgers, C. D., Kulawik, S. S., Worden, J., Sarkissian, E., Osterman, G., Steck, T., Luo, M., Eldering, A., Shephard, M., Worden, H., Lampel, M., Clough, S., Brown, P., Rinsland, C., Gunson, M., and Beer, R.: Tropospheric emission spectrometer: Retrieval method and error analysis, IEEE Trans. Geosci. Remote Sens., 44, 1297-1307, doi:10.1109/TGRS.2006.871234, 2006.

Brasseur, G. P., Hauglustaine, D. A., Walters, S., Rasch, P. J., Müller, J.-F., Granier, C., and Tie, X. X.: MOZART: A global 
chemical transport model for ozone and related chemical tracers: 1. Model description, J. Geophys. Res., 103, 28265-28289, 1998.

Chandra, S., Ziemke, J. R., Duncan, B. N., Diehl, T. L., Livesey, N. J., and Froidevaux, L.: Effects of the 2006 El Niño on tropospheric ozone and carbon monoxide: implications for dynamics and biomass burning, Atmos. Chem. Phys., 9, 4239-4249, doi:10.5194/acp-9-4239-2009, 2009.

Chen, Y., Li, Q., Randerson, J. T., Lyons, E. A., Kahn, R. A., Nelson, D. L., and Diner, D. J.: The sensitivity of CO and aerosol transport to the temporal and vertical distribution of North American boreal fire emissions, Atmos. Chem. Phys., 9, 6559-6580, doi:10.5194/acp-9-6559-2009, 2009.

Christian, H. J., Blakeslee, R. J., Boccippio, D. J., Boeck, W. L., Buechler, D. E., Driscoll, K. T., Goodman, S. J., Hall, J. M., Koshak, W. J., Mach, D. M., and Stewart, M. F.: Global frequency and distribution of lightning as observed from space by the optical transient detector, J. Geophys. Res., 108, 4005, doi:10.1029/2002JD002347, 2003.

Divakarla, M., Barnet, C., Goldverg, M., Maddy, E., Irion, F., Newchurch, M., Liu, X. P., Wolf, W., Flynn, L., Labow, G., Xiong, X. Z., Wei, J., and Zhou, L.: Evaluation of Atmospheric Infrared Sounder ozone profiles and total ozone retrievals with matched ozonesonde measurements, ECMWF ozone data, and Ozone Monitoring Instrument retrievals, J. Geophys. Res., 113, D15308, doi:10.1029/2007JD009317, 2008.

Fishman, J., Watson, C. E., Larsen, J. C., and Logan, J. A.: Distribution of tropospheric ozone determined from satellite data, J. Geophys. Res., 95, 3599-3617, 1990.

Giglio, L., Descloitres, J., Justice, C. O., and Kaufman, Y. J.: An enhanced contextual fire detection algorithm for MODIS. Remote Sensing of Environment, 87, 273-282, 2003.

Giglio, L., van der Werf, G. R., Randerson, J. T., Collatz, G. J., and Kasibhatla, P.: Global estimation of burned area using MODIS active fire observations, Atmos. Chem. Phys., 6, 957974, doi:10.5194/acp-6-957-2006, 2006.

Guenther, A., Karl, T., Harley, P., Wiedinmyer, C., Palmer, P. I., and Geron, C.: Estimates of global terrestrial isoprene emissions using MEGAN (Model of Emissions of Gases and Aerosols from Nature), Atmos. Chem. Phys., 6, 3181-3210, doi:10.5194/acp-63181-2006, 2006.

Hack, J. J.: Parameterization of moist convection in the NCAR community climate model (CCM2), J. Geophys. Res., 99, 55515568, doi:10.1029/93JD03478, 1994.

Horowitz, L., Walters, S., Mauzerall, D., Emmons, L., Rasch, P., Granier, C., Tie, X., Lamarque, J.-F., Schultz, M., Tyndall, G., Orlando, J., and Brasseur, G.: A global simulation of tropospheric ozone and related tracers: Description and evaluation of MOZART, version 2, J. Geophys. Res., 108, 4784, doi:10.1029/2002JD002853, 2003.

Hudman, R. C., Jacob, D. J., Turquety, S., Leibensperger, E. M., Murray, L. T., Wu, S., Gilliland, A. B., Avery, M., Bertram, T. H., Brune, W., Cohen, R. C., Dibb, J. E., Flocke, F. M., Fried, A., Holloway, J., Neuman, J. A., Orville, R., Perring, A., Ren, X., Sachse, G. W., Singh, H. B., Swanson, A., and Wooldridge, P. J.: Surface and lightning sources of nitrogen oxides over the United States: Magnitudes, chemical evolution, and outflow, J. Geophys. Res., 112, D12S05, doi:10.1029/2006JD007912, 2007.
Jacob, D. J., Heikes, B. G., Fan, S.-M., Logan, J. A., Mauzerall, D. L., Bradshaw, J. D., Singh, H. B., Gregory, G. L., Talbot, R. W., Blake, D. R., and Sachse, G. W.: Origin of ozone and $\mathrm{NO}_{\mathrm{x}}$ in the tropical troposphere: a photochemical analysis of aircraft observations over the South Atlantic Basin, J. Geophys. Res., 101, 24235-24350, 1996.

Jourdain, L., Worden, H. M., Bowman, K., Li, Q. B., Eldering, A., Kulawik, S. S., Osterman, G., Boersma, K. F., Fisher, B., Rinsland, C. P., Beer, R., and Gunson, M.: Tropospheric vertical distribution of tropical Atlantic ozone observed by TES during the northern African biomass burning season, Geophys. Res. Lett., 34, L04810, doi:10.1029/2006GL028284, 2007.

Jourdain, L., Kulawik, S. S., Worden, H. M., Pickering, K. E., Worden, J., and Thompson, A. M.: Lightning $\mathrm{NO}_{\mathrm{x}}$ emissions over the USA constrained by TES ozone observations and the GEOS-Chem model, Atmos. Chem. Phys., 10, 107-119, doi:10.5194/acp-10-107-2010, 2010.

Kalnay E., Kanamitsu, M., Kistler, R., Collins, W., Deaven, D., Gandin, L., Iredell, M., Saha, S., White, G., Woollen, J., Zhu, Y., Leetmaa, A., Reynolds, B., Chelliah, M., Ebisuzaki, W., Higgins, W., Janowiak, J., Mo, K.C., Ropelewski, C., Wang, J., Jenne, R., and Joseph, D.: The NCEP/NCAR 40-year reanalysis project, B. Am. Meteorol. Soc., 77, 437-471, 1996.

Komala, N., Saraspriya, S., Kita, K., and Ogawa, T.: Tropospheric ozone behavior observed in Indonesia, Atmos. Environ., 30, 1851-1856, 1996.

Kulawik, S. S., Worden, J., Eldering, A., Bowman, K., Gunson, M., Osterman, G. B., Zhang, L., Clough, S., Shephard, M. W., and Beer, R.: Implementation of cloud retrievals for Tropospheric Emission Spectrometer (TES) atmospheric retrievals: part 1. Description and characterization of errors on trace gas retrievals, J. Geophys. Res., 111, D24204, doi:10.1029/2005JD006733, 2006.

Lacis, A. A., Wuebbles, D. J., and Logan, J. A.: Radiative forcing of climate by changes in the vertical distribution of ozone, J. Geophys. Res., 95, 9971-9981, doi:10.1029/JD095iD07p09971, 1990.

Levelt, P. F., Hilsenrath, E., Leppelmeier, G. W., van den Oord, G. H. J., Bhartia, P. K., Tamminen, J., de Haan, J. F., and Veefkind, J. P.: Science objectives of the Ozone Monitoring Instrument, IEEE Trans. Geosci. Remote Sens., 44, 1199-1208, doi:10.1109/TGRS.2006.872336, 2006a.

Levelt, P. F., van den Oord, G. H. J., Dobber, M. R., Mälkki, A., Visser, H., de Vries, J., Stammes, P., Lundell, J. O. V., and Saari, H.: The Ozone Monitoring Instrument, IEEE Trans. Geosci. Remote Sens., 44, 1093-1101, doi:10.1109/TGRS.2006.872333, $2006 \mathrm{~b}$.

Levy, H.: Normal atmosphere: Large radical and formaldehyde concentrations predicted, Science, 173, 141-143, 1971.

Lin, S. J. and Rood, R. B.: Multidimensional flux form semiLagrangian transport schemes, Mon. Weather Rev., 124, 20462070, 1996.

Liu, J. J., Jones, D. B. A., Worden, J. R., Noone, D., Parrington, M., and Kar, J.: Analysis of the summertime buildup of tropospheric ozone abundances over the Middle East and North Africa as observed by the Tropospheric Emission Spectrometer instrument, J. Geophys. Res., 114, D05304, doi:10.1029/2008JD010993, 2009.

Liu, J. J., Jones, D. B. A., Zhang, S., and Kar, J.: Influence of interannual variations in transport on summertime abundances of ozone over the Middle East, J. Geophys. Res., 116, D20310, 
doi:10.1029/2011JD016188, 2011.

Livesey, N. J., Snyder, W. V., Read, W. G., and Wagner, P. A.: Retrieval algorithms for the EOS Microwave Limb Sounder (MLS) instrument, IEEE Trans. Geosci. Remote Sens., 44, 1144-1155, 2006.

Livesey, N. J., Filipiak, M., Froidevaux, L., Read, W., Lambert, A., Santee, M., Jiang, J., Waters, J., Drouin, B., Cofield, R., Cuddy, D., Fuller, R., Jarnot, R., Jiang, Y., Knosp, B., Li, Q. B., Schwartz, M., Snyder, W., Stek, P., Wagner, P., Pumphrey, H., Avery, M., Browell, E., Christiensen, L., Edwards, D., Emmons, L., Fahey, D., Gao, R., Loewenstein, M., Lopez, J., Osterman, G., Sachse, G., and Webster, C.: Validation of EOS MLS $\mathrm{O}_{3}$ and CO observations in the upper troposphere and lower stratosphere, J. Geophys. Res., 113, D15S02, doi:10.1029/2007JD008805, 2008.

Livesey, N. J., Read, G. W., Froidevaux, L., Lambert, A., Manney, L. G., Pumphrey, C. H., Santee, L. M., Schwartz, J. M., Wang, S., Cofield, E. R., Cuddy, T. D., Fuller A. R., Jarnot, F. R., Jiang, H. J., Knosp, W. B., Stek C. P., Wagner, A. P., and Wu, L. D.: Version 3.3 Level 2 data quality and description document, Jet Propulsion Laboratory, 2011.

Logan, J. A., Prather, M. J., Wofsy, S. C., and McElroy, M. B.: Tropospheric chemistry: A global perspective, J. Geophys. Res., 86, 7210-7254, 1981.

Logan, J. A., Megretskaia, I., Nassar, R., Murray, T. L., Zhang, L., Bowman, W. K., Worden, W. H., and Luo, M.: Effects of the 2006 El Niño on tropospheric composition as revealed by data from the Tropospheric Emission Spectrometer (TES), Geophys. Res. Lett., 35, L03816, doi:10.1029/2007GL031698, 2008.

Luo, M., Rinsland, C. P., Logan, J. A., Worden, J., Kulawik, S., Eldering, A., Goldman, A., Shephard, M. W., Gunson, M., and Lampel M.: Comparison of carbon monoxide measurements by TES and MOPITT: The influence of a priori data and instrument characteristics on nadir atmospheric species retrievals, J. Geophys. Res., 112, D09303, doi:10.1029/2006JD007663, 2007.

Martin, R. V., Sauvage, B., Folkins, I., Sioris, C. E., Boone, C., Bernath, P., and Ziemke, J.: Space-based constraints on the production of nitric oxide by lightning, J. Geophys. Res., 112, D09309, doi:10.1029/2006JD007831, 2007.

McLinden, C. A., Olsen, S. C., Hannegan, B., Wild, O., Prather, M. J., and Sundet, J.: Stratospheric ozone in 3-D models: A simple chemistry and the cross-tropopause flux, J. Geophys. Res., 105, 14653-14666, 2000.

McPeters, R., Kroon, M., Labow, G., Brinksma, E., Balis, D., Petropavlovskikh, I., Veefkind, J. P., Bhartia, P. K., and Levelt, P. F.: Validation of the Aura Ozone Monitoring Instrument total column ozone product, J. Geophys. Res., 113, D15S14, doi:10.1029/2007JD008802, 2008.

Moorthi, S. and Suarez, M. J.: Relaxed Arakawa-Schubert: A parameterization of moist convection for general circulation models, Mon. Weather Rev., 120, 978-1002, 1992.

Murray, L. T., Jacob, D. J., Logan, J. A., Hudman, R. C., and Koshak, W. J.: Optimized regional and interannual variability of lightning in a global chemical transport model constrained by LIS/OTD satellite data, J. Geophys. Res., submitted, 2012.

Nassar, R., Logan, J. A., Worden, H. M., Megretskaia, I. A., Bowman, K. W., Osterman, G. B., Thompson, A. M., Tarasick, D. W., Austin S., Claude, H., Dubey, M. K., Hocking, W. K., Johnson, B. J., Joseph, E., Merrill, J., Morris, G. A., Newchurch, M., Oltmans, S. J., Posny, F., Schmidlin, F. J.,
Vomel, H., Whiteman, D. N., and Witte, J. C.: Validation of Tropospheric Emission Spectrometer (TES) nadir ozone profiles using ozonesonde measurements, J. Geophys. Res., 113, D15S17, doi:10.1029/2007JD008819, 2008.

Nassar, R., Logan, J. A., Megretskaia, I. A., Murray, L. T., Zhang, L., and Jones, D. B. A.: Analysis of tropospheric ozone, carbon monoxide and water vapor during the 2006 El Niño using TES observations and the GEOS-Chem model, J. Geophys. Res., 114, D17304, doi:10.1029/2009JD011760, 2009.

Olivier, J. G. J. and Berdowski, J. J. M.: Global emissions sources and sinks, in: The Climate System, edited by: Berdowski, J., Guicherit, R., and Heij, B. J., pp. 33-78, A. A. Balkema, Lisse, Netherlands, 2001.

Oman, L. D., Ziemke, J. R., Douglass, A. R., Waugh, D. W., Lang, C., Rodriguez, J. M., and Nielsen, J. E.: The response of tropical tropospheric ozone to ENSO, Geophys. Res. Lett., 38, L13706, doi:10.1029/2011GL047865, 2011.

Osterman, G. B., Kulawik, S. S., Worden, H., Richards, N. A., Fisher, B. M., Eldering, A., Shephard, M. W., Froidevaux, L., Labow, G., Luo, M., Herman, R. L., Bowman, K. W., and Thompson, A. M.: Validation of Tropospheric Emission Spectrometer (TES) measurements of the total, stratospheric, and tropospheric column abundance of ozone, J. Geophys. Res., 113, D15S16, doi:10.1029/2007JD008801, 2008.

Parkinson, C. L.: Aqua: An Earth-observing satellite mission to examine waterand other climate variables, IEEE Transactions on Geoscience and Remote Sensing, 41, 173-183, doi:10.1109/TGRS.2002.808319, 2003.

Pickering, K. E., Wang, Y. S., Tao, W. K., Price, C., and Muller, J. F.: Vertical distributions of lightning $\mathrm{NO}_{\mathrm{x}}$ for use in regional and global chemical transport models, J. Geophys. Res., 103, 31203 31216, 1998.

Price, C. and Rind, D. H.: A simple lightning parameterization for calculating global lightning distributions, J. Geophys. Res., 97, 9919-9933, 1992.

Price, C. and Rind, D. H.: What determines the cloud-to-ground lightning fraction in thunderstorms?, Geophys. Res. Lett., 20, 463-466, 1993.

Price, C. and Rind, D. H.: Modeling global lightning distributions in a general circulation model, Mon. Weather Rev., 122, 19301939, 1994.

Randerson, J. T., Liu, H., Flanner, M. G., Chambers, S. D., Jin, Y., Hess, P. G., Pfister, G., Mack, M. C., Treseder, K. K., Welp, L. R., Chapin, F. S., Harden, J. W., Goulden, M. L., Lyons, E., Neff, J. C., Schuur, E., and Zender, C. S.: The impact of boreal forest fire on climate warming, Science, 314, 1130-1132, 2006.

Rienecker, M.: File specification for GEOS-5 DAS gridded output, NASA Goddard Space Flight Center, 2008.

Sander, S. P., Friedl, R. R., DeMore, W. B., Golden, D. M., Kurylo, M. J., Hampson, R. F., Huie, R. E., Moortgat, G. K., Ravishankara, A. R., Kolb, C. E., and Molina, M. J.: Chemical Kinetics and Photochemical Data for Use in Stratospheric Modeling, Technical Report JPL Publication 00-3, Jet Propulsion Laboratory, Pasadena, CA, 2000.

Sauvage, B., Martin, R. V., van Donkelaar, A., Liu, X., Chance, K., Jaeglé, L., Palmer, P. I., Wu, S., and Fu, T.-M.: Remote sensed and in situ constraints on processes affecting tropical tropospheric ozone, Atmos. Chem. Phys., 7, 815-838, doi:10.5194/acp-7-815-2007, 2007. 
Schoeberl, M. R., Douglass, A. R., Hilsenrath, E., Bhartia, P. K., Beer, R., Waters, J. W., Gunson, M. R., Froidevaux, L., Gille, J. C., Barnett, J. J., Levelt, P. F., and DeCola, P.: Overview of the EOS Aura mission, IEEE Trans. Geosci. Remote Sens., 44, 1066-1074, doi:10.1109/TGRS.2005.861950, 2006.

Shim, C., Li, Q. B., Luo, M., Kulawik, S., Worden, H., Worden, J., Eldering, A., Avery, M., Diskin, G., Sachse, G.: A. Weinheimer, D. Knapp, D. Montzca, and T. Campos, Satellite observations of Mexico City pollution outflow from the Tropospheric Emissions Spectrometer (TES), Atmos. Environ., 43, 1540-1547, doi:10.1016/j.atmosenv.2008.11.026, 2009.

Tan, W., Geller, M. A., Pawson, S., and da Silva, A. M.: A case study of excessive subtropical transport in the stratosphere of a data assimilation system, J. Geophys. Res., 109, D11102, doi:10.1029/2003JD004057, 2004.

Thompson, A. M., Pickering, K. E., McNamara, D. P., Schoeberl, M. R., Hudson, R. D., Kim, J. H., Browell, E. V., Kirchhoff, V. W. J. H., and Nganga, D.: Where did tropospheric ozone over southern Africa and the tropical Atlantic come from in October 1992? Insights from TOMS, GTE TRACE-A and SAFARI 1992, J. Geophys. Res., 101, 24251-24278, doi:10.1029/96JD01463, 1996.

Thompson, A. M., Witte, J. C., Hudson, R. D., Guo, H., Herman, J. R., and Fujiwara, M.: Tropical tropospheric ozone and biomass burning, Science, 291, 2128-2132, doi:10.1126/science.291.5511.2128, 2001.

van der Werf, G. R., Randerson, J. T., Giglio, L., Collatz, G. J., Kasibhatla, P. S., and Arellano Jr., A. F.: Interannual variability in global biomass burning emissions from 1997 to 2004, Atmos. Chem. Phys., 6, 3423-3441, doi:10.5194/acp-6-3423-2006, 2006.

Wang, Y., Jacob, D. J., and Logan, J. A.: Global simulation of tropospheric $\mathrm{O}_{3}-\mathrm{NO}_{\mathrm{x}}$-hydrocarbon chemistry, 1 . Model formulation, J. Geophys. Res., 103, 10713-10726, 1998.

Waters, J. W., Froidevaux, L., Harwood, R. S., Jarnot, R. F., Pickett, H. M., Read, W. G., Siegel, P. H., Cofield, R. E., Filipiak, M. J., Flower, D. A., Holden, J. R., Lau, G. K., Livesey, N. J., Manney, G. L., Pumphrey, H. C., Santee, M. L., Wu, D. L., Cuddy, D. T., Lay, R. R., Loo, M. S., Perun, V. S., Schwartz, M. J., Stek, P. C., Thurstans, R. P., Boyles, M. A., Chandra, K. M., Chavez, M. C., Chen, G. S., Chudasama, B. V., Dodge, R., Fuller, R. A., Girard, M. A., Jiang, J. H., Jiang Y. Knosp, B. W., LaBelle, R. C., Lam, J. C., Lee, K. A., Miller, D., Oswald, J. E., Patel, N. C., Pukala, D. M., Quintero, O., Scaff, D. M., Van Snyder, W., Tope, M. C., Wagner, P. A., and Walch, M. J.: The Earth Observing System Microwave Limb Sounder (EOS MLS) on the Aura satellite, IEEE Trans. Geosci. Remote Sens., 44, 10751092, doi:10.1109/TGRS.2006.873771, 2006.
Weaver, C. J., Douglass, A. R., and Rood, R. B.: Thermodynamic balance of three-dimensional stratospheric winds derived from a data assimilation procedure, J. Atmos. Sci., 50, 2987-2993, 1993.

Wild, O., Zhu, X., and Prather, M. J.: FAST-J: Accurate simulation of in- and below-cloud photolysis in tropospheric chemical models, J. Atmos. Chem., 37, 245-282, 2000.

Worden, H. M., Logan, J. A., Worden, J. R., Beer, R., Bowman, K., Clough, S. A., Eldering, A., Fisher, B. M., Gunson, M. R., Herman, R. L., Kulawik, S. S., Lampel, M. C., Luo, M., Meqretskaia, I. A., Osterman, G. B., and Shephard, M. W.: Comparisons of Tropospheric Emission Spectrometer (TES) ozone profiles to ozonesondes: Methods and initial results, J. Geophys. Res., 112, D03309, doi:10.1029/2006JD007258, 2007.

Yevich, R. and Logan, J. A.: An assessment of biofuel use and burning of agricultural waste in the developing world, Global Biogeochem. Cycles, 17, 1095, doi:10.1029/2002GB001952, 2003.

Zhang, G. J. and McFarlane, N. A.: Sensitivity of climate simulations to the parameterization of cumulus convection in the Canadian climate centre general circulation model, Atmos.-Ocean, 33, 407-446, 1995.

Zhang, Q., Streets, D. G., Carmichael, G. R., He, K. B., Huo, H., Kannari, A., Klimont, Z., Park, I. S., Reddy, S., Fu, J. S., Chen, D., Duan, L., Lei, Y., Wang, L. T., and Yao, Z. L.: Asian emissions in 2006 for the NASA INTEX-B mission, Atmos. Chem. Phys., 9, 5131-5153, doi:10.5194/acp-9-5131-2009, 2009.

Zhang, L., Li, Q. B., Jin, J., Liu, H., Livesey, N., Jiang, J. H., Mao, Y., Chen, D., Luo, M., and Chen, Y.: Impacts of 2006 Indonesian fires and dynamics on tropical upper tropospheric carbon monoxide and ozone, Atmos. Chem. Phys., 11, 10929-10946, doi:10.5194/acp-11-10929-2011, 2011.

Ziemke, J. R., Chandra, S., Duncan, B. N., Schoeberl, M. R., Torres, O., Damon, M. R., and Bhartia, P. K.: Recent biomass burning in the tropics and related changes in tropospheric ozone, Geophys. Res. Lett., 36, L15819, doi:10.1029/2009GL039303, 2009. 